\title{
11 Eylül 2001 ve 13 Kasım 2015 Terör Saldırılarının Siyasete Etkileri: ABD ve Fransa'nın Terörle Savaş Yaklaşımı*
}

\section{Political Consequences of Terrorist Attacks of September 11, 2001 and November 13, 2015: War on Terrorism}

\author{
Aslıhan Yeniçeri Altıntaşa,*
}

${ }^{a}$ Arş. Gör., Muş Alparslan Üniversitesi, , İktisadi ve İdari Bilimler Fakültesi, Siyaset Bilimi ve Kamu Yönetimi Bölümü, 49270, Muş/Türkiye. ORCID: 0000-0001-8480-3385

\section{MAKALE BILLGISİ}

Makale Geçmişi:

Başvuru tarihi: 31 Mart 2020

Düzeltme tarihi: 13 Ekim 2020

Kabul tarihi: 21 Ekim 2020

\section{Anahtar Kelimeler:}

Terörle Savaş,

Terörün Siyasi Sonuçları,

ABD11 Eylül Saldırıları,

Fransa 13 Kasım Saldırıları.
ÖZ

Bu araştırmanın amacı ABD'de 11 Eylül 2001 yılında ve Fransa'da 13 Kasım 2015 yılında gerçekleşen terör saldırıları ardından uygulanan terörle savaş yaklaşımının karşılaştırmalı analizini yapmaktır. Çalışmada nitel araştırma yöntemi uygulanarak içerik analizi tekniği kullanılmıștır. Terör saldırıları sonrasında George W. Bush ve François Hollande'in yaptıkları konuşma metinleri analiz edilerek terörle savaş, devletin ve ulusun gücü, düşmanın kapasitesi ve kötülügü, uluslararası iș birliği, askeri ve idari düzenlemeler olarak 5 tema olușturulmuş ve her bir tema için kategoriler belirlenmiştir. Elde edilen bulgulara göre, ABD ve Fransa'nın terörle mücadelede uyguladıkları terörle savaş yaklaşımı temelde dört ortak eğilim göstermektedir: terör saldırıları sonrasında yapılan düzenlemelerin güvenlik konusu haline getirme eğilimi, İslam'la değil cihatçı İslam'la mücadele etmeyi hedefledikleri, ulusal ve dıș politikada kolluk ve askeri kuvvetlerin ön plana çıkması.

\section{ART ICLE INFO}

\section{Article history:}

Received 31March 2020

Received in revised form 13 October 2020

Accepted 21October 2020

\section{Keywords:}

War on Terror,

Political Consequences of Terror,

9/11 Attacksi

November 13 Attacks.

\section{A B S T R A C T}

The purpose of this research is to analyze the effects of political consequences of terror by making a comparative analysis of September 11, 2001 in the USA and on the attacks of November 13, 2015 in France. In the study, content analysis technique was used by applying qualitative research method. After terrorist attacks, the speech texts of George W. Bush and François Hollande were analyzed and 5 themes were created as war on terrorism, power of the state and nation, capacity and evil of the enemy, international cooperation, military and administrative regulations, and categories were determined for each theme. According to the results, war on terrorism approach implemented by the USA and France in war on terrorism shows four common trends: the tendency to make the regulations made after terrorist attacks a security issue, aim to fight jihadist Islam, not Islam, the prominence of law enforcement and military forces in national and foreign policy.

\section{Giriş}

Terör saldırıları sadece iç politikayı etkilemekte kalmayıp, bölgesel ve uluslararası politikalarıda etkilemektedir. Terörizmin büyük bir güvenlik tehdidi haline gelmesi ve terör saldırıların uluslararası boyut kazanması terör saldırılarını önemli bir çalışma alanı haline getirmektedir
(Silke, 2008). 11 Eylül 2001 tarihinde El Kaide ABD’nin sembolik öneme sahip kurum ve yapılarına saldırmıştır. 11 Eylül saldırıları olarak bilinen bu terör saldırıları sonrasında terörün akademik olarak çalışılması artmıştır. 1971 ve 2002 döneminde yayınlanan 14.006 makalenin \%54'ünü 20012002 yılları arasında yazılmıştır (Jackson, 2012:2). 11 Eylül Saldırıları sonrası oluşturulan 'terörle savaş' yaklaşımı ise

*Bu çalışma yazarın Aslıhan Yeniçeri Altıntaş'ın 2020 yılında Doç. Dr. İdil Tunçer Kılavuz danışmanlığında İstanbul Medeniyet Üniversitesi Lisansüstü Enstitüsü Siyaset Bilimi ve Kamu Yönetimi Anabilim Dalı'nda yürüttüğü "Yalnız Kurtlar” ve Terör Örgütleri

Tarafından Yapılan Terör Saldırılarının Siyasete Etkileri” başlıklı doktora tezinden türetilmiştir.

** Sorumlu yazar/Corresponding author

e-posta: a.altintas@alparslan.edu.tr 
dıș politikayı şekillendirici bir etki göstermiștir (Cox, 2002). Öncelikle 11 Eylül saldırıları ABD'nin 10 yıldan fazla bir süre askeri kapasitesini artıran bir etki sergilemesine yol açmıştır. 11 Eylül sonrası Afganistan ve Irak'a askeri müdahale ABD'nin dış politikasında büyük bir değişimi gösterirken, ulusal güvenlik alanında iki düzineden fazla güvenlik düzenlemesiyle ulusal politikadaki değişimi gözler önüne sermektedir (Benjamin, 2006: viii).

11 Eylül saldırıları sonrasında uluslararası siyaset ve güvenlik anlayışı radikal bir şekilde değişmiştir. ABD uzun dönemli istikrar ve güvenlik arayışı içinde Soğuk Savaş sonrası döneme benzer şekilde, güvenlik anlayışını yeniden değerlendirmiştir (d'Abadie, 2003). 11 Eylül saldırıları uluslararası toplumu yeni tehdit ve zorluklar hakkında düşünmeye zorlamıştır ve saldırılar öncesinin güvenlik yönetimine değil artı güvensizlik yönetimine dayanmasında yol açmıştır (d'Abadie, 2003). 11 Eylül ABD'nin daha radikal ve uzlaşmaz bir model benimseyerek dış ve savunma politikasını etkilemiştir (d'Abadie, 2003). 11 Eylül saldırıları sonrasında ABD 2001 yılında Afganistan'a ve 2003 yılında Irak'a karşı askeri müdahalede bulunmuş ve terörle savaş yaklaşımını benimsemiştir. 11 Eylül saldırılarından yaklaşık 14 yıl sonra Fransa'da 13 Kasım 2015 tarihinde IŞID tarafindan yapılan 5 eş zamanlı saldırıya karşılık olarak, Fransız jetleri koalisyon güçleriyle askeri müdahalede bulunmuş ve terörle savaş yaklaşımını tercih etmiştir.

Terörle savaş yaklaşımı terörle mücadelede ağırlıklı olarak askeri usul ve yöntemlerin kullanılması olarak ifade edilebilirken, bu yaklaşım salt olarak askeri güce dayanmamaktadır. Terörle savaş yaklaşımı diplomasi ve uluslararası ilişkilerin ön plana çıktığı kapsamlı bir süreci ifade etmektedir. Bu yaklaşımın analiz edilebilmesi terör saldırıları sonrasından yapılan yasal değişimlere, terörü durdurmak amaciyla uygulanan yöntemlere ve siyasi liderlerin geliştirdikleri politikalara dikkat edilmesine bağlıdır.

Terör saldırıları sonrasında, terörle savaş yaklaşımının aksine, askeri usul ve yöntemlerin ikinci planda olduğu, idari ve yasal reformlarla terör saldırılarını sona erdirmeyi amaçlayan daha pasif yaklaşımları tercih eden ülkelerde bulunmaktadır. Bu yaklaşıma 11 Mart 2004 tarihinde El Kaide tarafindan Madrid'de tren istasyonlarında patlayan bombalar 191 kişinin hayatını kaybetmesine ve 1500 kişinin yaralanmasına yol açması gösterilebilir (Brandström ve Örtenwall, 2007:3). Avrupa'da gerçekleşen en kanlı terör saldırılardan biri olan 2004 Madrid tren istasyonlarında bomba patlatılması iç güvenlik sürecinin yeniden değerlendirilmesine yol açmıştır (Calamur, 2017).

Madrid'de patlayan bomların ardından 3 gün sonra seçim yapılmış ve hükümetteki Muhafazakâr Parti oy kaybı yaşamış ve Sosyalist Parti İspanyol Kongre seçimlerinde kazanan taraf olmuştur. El Kaide, İspanya'nın 2003 'te Irak Savaşı'na destek vermesinden dolayı hedef olarak seçildiğini belirtmiştir (Montalvo, 2011:1147). Terör saldırıları öncesi Muhafazakâr Partinin oy oranları seçim öncesi anketlere \%42- 43 arasında iken, saldırılar sonrası Irak’tan İspanyol birliklerini geri çekip ekonomik reformlara yönelen Sosyalist Parti kazanmıștır (Montalvo, 2011).

Madrid'te yapılan terör saldırılarının ardından terörle savaş yaklaşımı benimsenmemiş, bunun yerine görevdeki hükümet cezalandırılarak hükümet değişimi yaşanmış ve terör saldırılarına cevaben ulusal güvenlik alanında yeni düzenlemeler yapılmıştır. Örneğin, yeni bir tehdit ortamı belirlenerek, daha önceden ülkedeki cihatçıları belirleme üzerine sadece 140 ajan görevliyken, 2004 saldırısı sonrasında sosyal medya hesaplarını gözden geçrien, camileri araştıran, muhbirlerle iletişime geçen, aşırılık yanlılarını takip eden ve terörist ağlar hakkında bilgi toplamakla görevlilerin sayısı 3.000'e ulaşmıştır (Ballesterus, 2018:11; Calamur, 2017). İspanya'nın terörle mücadelesi idari reformlar üzerine inşa edilmiştir. Risk ve tehdit yönetimine odaklanılmış, hükümet gerekli tebdirleri alma yolunu seçerek istihbarat yeteneklerini geliştirmeyi tercih etmiştir ve İspanyollar bu yolları memnuniyetle karşılamıştır (Reinares, 2009: 367).

Teknik ve idari düzenlemelerin hâkim olduğu terörle mücadele yaklaşımını tercih eden İspanyollara kıyasla ABD ve Fransa daha kapsamlı ve sert tedbir ve düzenlemeler yaparak, terörle savaş yaklaşımını benimsemişlerdir. ABD'nin terörle savaş yaklaşımı uzun bir süre askerî açıdan hiç bitmeyecek bir savaş zinciri izlenimi vermiş, bunun aksine Fransa'nın terörle mücadele savaşının stratejik çerçeveside 13 Kasım saldırılarından sonra kısa soluklu bir askeri müdahaleyle sınırlı kalmıştır. Fransa'nın Sahel ${ }^{1}$ bölgesindeki askeri mevcudiyeti hesaba katılınca büyük resimde Fransa'nın terörle mücadelesinin ABD'nin yaklaşımıyla benzerlikleri dikkat çekmektedir (MignotMahdavi, 2020:4).

Terörle savaş ABD örneğinde olduğu gibi Afganistan ve Irak gibi farklı ülkelere doğrudan ve uzun dönemli askeri müdahaleleri ve Fransa örneğinde olduğu gibi Suriye'ye askeri uçaklarla bir gecede yapılan askeri müdahaleleri içerebilmektedir. Bu çalışma kapsamında, terörle mücadele politikasını 'terörle savaş' yaklaşımını benimsemekle birlikte farklı noktalara temas eden ve farklı uygulamaları benimseyen iki vaka seçilmiştir. ABD ve Fransa'nın yaşanan terör saldırıları sonrasında uyguladıkları terör savaş yaklaşımları nasıl farklılık gösterdiği sorusunun cevabı aranmıştır.

Terör saldırıları sonrasında yapılan idari ve yasal düzenlemelerin güvenlikleştirilmesi yani güvenlik konusu haline getirilmesi eğilimi dikkat çekmektedir (Dück \& Lucke, 2019). Terörle savaş yaklaşımı doğal olarak askeri yöntemlere ağırlık verirken, diğer yandan sivil özgürlükler (göz altına alma süreleri, telefon dinleme, email izleme vb.), yerli terörizmin göçmenlerle ilişkisi, olağanüstü hal gibi düzenlemelerle vatandaşların gündelik hayatlarını etkileyen yeni düzenlemeleri güvenliğin konusu haline getirmektedir. Örneğin, Fransa, 13 Kasım 2015 saldırıları sonrası olağanüstü hâl ilan etmiş ve polis kuvvetlerini güçlendirici yeni bir statü arayışına girmiştir (Schofiel, 2015).

\footnotetext{
${ }^{1}$ Mali, Nijer, Mortanya, Burkina Faso ve Çad'ı içeren bölge
} 
Terör saldırılarını gerçekleștiren teröristlerin bulundukları ülkelerin vatandaşları olan göçmen asıllılardan oluşmasına yerli terörizme- olan vurgu göçmenlerin güvenlik konusu haline getirilmesine yol açmaktadır. Göçmenlerin durumununde güvenlik alanına taşınması kendisini Fransız örneğinde göstermektedir. Eski Fransız kolonilerinden gelen göçmenlerin durumu terör saldırılarının ardından tartışma konusu olmuş ve entegrasyon sorununu gündeme getirmiştir (Dück \& Lucke, 2019:3). Diğer taraftan Fransa, vatandaşlıktan çıkarma teklifiyle bir adım ileriye gitmektedir (BBC, 2016). Terör örgütlerine destek için Suriye'ye giden ve sonra geri dönüp terör faaliyetleri içerisinde olanları vatandaşlıktan çıkarma uzunca bir süre tartışılmıştır. Göçmen asıllı vatandaşlarının durumu güvenlik esaslı olarak değerlendirilmesi ABD içinde geçerlidir. 11 Eylül hava korsanlarına liderlik eden pilotlar Almanya'da radikalleştikten sonra ABD'ye saldırdıklarını buna karşın 7 Temmuz'da Londra'ya saldıranlar İngiltere'de radikalleşmişlerdir (Silber ve Bhatt, 2007:14). Yerli terörizm giderek daha fazla bireyi etkilemekte ve terör saldırılarıyla göçmenlerin ilişkilendirilmesine yol açmaktadır.

El Kaide tarafından yapılan 11 Eylül 2001 saldırısı ve IŞID tarafindan yapılan 13 Kasım 2015 saldırılarından sonra ABD Başkanı George G. Bush ve Fransa Cumhurbaşkanı François Hollande'in terör saldırıları sonrasında tercih ettikleri 'terörle savaş' yaklaşımı irdelenmiștir. Bush'un 11 Eylül saldırılarıyla ilgili konuşmaları literatürde sıkça analiz edilen konulardan birisi olmuştur. Bush'un konuşmasını analiz eden Dück ve Lucke, (2019:3), askerî açıdan uzun sürecek bir savaş olacağına dair özel bir uyarıda dikkat çekerek Bush'un konuşmasının savaş eylemleri vurgusunun altında yatan amacının askeri eylemler için meşruiyet sağlamak olduğunu belirtmektedir. Başka bir ülkede askeri operasyon yapabilmek için savaş koşullarının oluşması gerekmekte ve terör örgtünün savaş eylemleri uyguladığı gerekçesi askeri müdahale için gerekli altyapıyı sağlamak için kullanılmıştır.

Bush'un konuşması Müslümanları doğrudan ilgilendiren birçok kısım barındırmaktadır. Bush 11 Eylül sonrası yaptığı konuşmasında, masumları öldüren Müslümanların hedefte olduğu, ancak diğer Müslümanlarında niyet ve çabalarını açıkça göstermelerinin beklendiği bir resim çizmiştir (Bush, 2001). Diğer yandan bir medeniyet savaşından bahsedilmiştir. Bush'un terörle savaş retoriği dinin değil ideoloji ve fikirlerin üzerine kurarak, özgürlük savaşını zülmün yükselişini engelleme üzerine bir uyuşmazlık çatışmasına kurmuştur (Abdo, 2015). Sonuçta, Bush'un konuşmasında terörle savaşın İslam'a karşı bir savaş olmadığı siyasi ve ideolojik unsurlara yönelik olduğu belirtilmektedir. $\mathrm{Bu}$ noktada, Ortadoğu'nun liderlerinin üzerine sorumluluk düşmekte, bazı evrensel kurallara uymaları ve terörle mücadelede herkesin gerekli rolü üstlenmesi gerekmektedir (Abdo, 2015). Bu minvalde, terörle savaş yaklaşımı özgürlük ve demokrasi yolunda bir gereklilik olarak sunulmaktadır.

Bush'un konuşması birçok kez çalışılmışken, Hollande'ın konuşmasının içerik analizi literatürde çalışılmamıştır. Bu çalışmayla birlikte, Hollande'in konuşması içerik ve betimsel analizi yapılarak, Bush'un konuşmasıyla karşılaştırmalı analizinin yapılması amaçlanmıştır. Böylelikle iki farklı terörle savaş yaklaşımının analizi yapılarak literatüre katkı yapılması hedeflenmektedir.

ABD ve Fransa'da yaşanan terör saldırıları sonrası uygulanan 'terörle savaş' yaklaşımı karşılaştırmalı analiz yöntemi uygulanarak incelenmiştir. İki liderin konuşma metinleri içerik analizi tekniği uygulanarak, 5 tema oluşturulup her bir tema için kategoriler oluşturulmuştur. Tematik analiz yapılarak alt kategoriler belirlenmiştir. Sonrasında, Bush ve Hollande'in bu kategoriler hakkında metinlerde bildirdikleri görüşleri analiz edilmiştir. Daha sonra betimsel analiz, tema analizin devamı olarak kullanılmış ve iki liderin konuşma metinlerinden doğrudan alıntılar yapılarak öncelikle yorum yapılmadan verilmiş ve araştırmanın iç geçerliliğinin artıracak şekilde temaya ilişkin betimlemeler yapılması tercih edilmiştir (Günbayı, 2019). Böylelikle ilk aşamada temalar belirlendikten sonra kategoriler oluşturulmuş, daha sonra betimsel analiz yapılmış ve metinler analiz edildikten sonra iki liderin terörle savaş yaklaşımı karşılaştırmalı olarak sunulmuştur.

Çalışma sonunda elde edilen bulgular iki liderin terörle savaş yaklaşımını benzer gerekçeler üzerine inşa ettiklerini;

- Askeri operasyon ve yeni yasal düzenlemeleri hayata geçirme niyetlerini;

- İdari düzenlemeler yapacaklarını;

- Vatandaşlıktan çıkarma gibi ciddi düzenlemeler istediklerini;

- İslam'a karşı değil Cihatçı İslam'la mücadele etmeyi hedeflediklerini;

- Uluslararası iş birliğine ihtiyaç duyduklarını göstermektedir.

İki liderin konuşmalarında, terörle savaş yaklaşımının askeri boyutu göze çarpmakla birlikte askeri kuvvetlerin ve polis güçlerinin yanında istihbarat güçlerinin geliştirilmesi hedefi tespit edilmiştir. İki liderin devletin kurumlarına destek veren vatandaşlarla birlikte kapsayıcı bir mücadele resmi çizdikleri görülmektedir. İki liderin terörle savaş yaklaşımının ortak yanlarına rağmen, Bush'un askeri yöntemleri Afganistan'dan Irak'a yayan küresel bir yol izlemiştir. Hollande'in terörle savaş yaklaşımında Suriye'ye uluslararası koalisyon kapsamında yapılan müdahalelerden bir adım ileri giderek kısıtlı bir askeri müdahale yapılmıştır. Sonuçta, iki ülkenin terörle savaş yaklaşımının kapsam ve boyut açısından aslında birbirlerinden farklı oldukları görülmektedir.

Ayrıca, bu devletlerin terörle savaş yaklaşımının 3 alanda birbirlerine yaklaştıkları tespit edilmiştir. Birinci olarak göçmenlik ve sivil haklar gibi konuların güvenliğin konusu haline getirilmesidir. İkinci benzer özellik, terörle savaş yaklaşımı iki ülke içinde ulusal ve dış politika açısından yeni düzenlemeleri beraberinde getirmesiyle şekillendirici bir özellik kazanmasıdır. ABD ve Fransa'nın terörle savaş yaklaşımının birbirlerine yaklaştıkları üçüncü özellik, askeri ve polis kuvvetlerinin genişletilmesidir.

\section{Yöntem ve Uygulama}

Dünyada yerel ya da uluslararası terör faaliyetlerinden mustarip olmayan ülkelerin sayısı giderek azalmaktadır. Küresel düzeyde terörizm faaliyetleri beraberinde terörle 
mücadele hareketlerini getirmiştir. 11 Eylül terörist saldırıları, tüm dünyaya bir ülke ne kadar güçlü olursa olsun bazı durumlar karşısında hala kırılgan olunabileceğini göstermiştir. $\mathrm{Bu}$ yüzdendir ki, 9/11 olarak literatürde yer alan bu saldirılar hakkında hazırlanan final raporunda saldırılar "11 Eylül 2001, Amerika Birleşik Devletleri tarihinde eşi benzeri görülmemiş bir şok ve acı veren bir gündü. Ulus hazırlıksızdı" olarak tanımlanmaktadır (9/11 Komisyon Raporu:1). El Kaide terör saldırısı yapmış, ABD' için sembolik özellikleri olan hedefleri vurmayı tercih etmiştir. $\mathrm{Bu}$ hedeflere eş zamanlı beş saldırı gerçekleştirmiştir. Yaklaşık 50.000 kişinin çalıştığı İkiz Kuleler olarak bilinen Dünya Ticaret Merkezi ve Pentagon Binasına saldırı gerçekleştirilmiştir. Saldırılar bununla sınırlı kalmamış, büyük ihtimalle Beyaz Saray ya da başkenti hedef almasına rağmen bir yolcu tarafindan engellenerek Pennsylvania'nın güneyine yapılmıştı. İkiz Kulelere yapılan saldırılarda 2600'den fazla; Pentagon Saldırısında 125 ve dördüncü uçağın saldırısında 256 kişi hayatını kaybetmişti (9/11 Eylül Komisyon Raporu). Saldırıların El Kaide terör örgütü adına gerçekleştirilmesi akabinde terörle savaş yaklaşımı geliştirilmiştir.

Fransa'da terör saldırılardan mustarip olan ülkelerin başında gelmektedir. 2013-2016 yılları arasında, Avrupa'da meydana gelen saldırıların neredeyse yarısı, 10 saldırı, 4 saldırı teşebbüsü ve 28 saldırı planı Fransa'da gerçekleşmiştir (Naidenov, 2020:2). 2013-2016 yıllarını kapsayan dönemde Fransa'da meydana gelen saldırılarsa terörle mücadele yaklaşımını doğrudan etkilemiştir. 7-9 Ocak 2015 yılları arasında Charlie Hebdo dergisi editör ve çalışanlarına yönelik saldırıyı, Yahudilerin işlettiği bir markete yapılan ve 17 kişinin ölümüyle sonuçlanan bir saldırı izlemiş, daha sonra 13 Kasım'da Paris'te yapılan 5 eş zamanlı terör saldırısı 130 kişinin hayatına mal olmuş ve sonrasında Bastille Günün'de Nice'te toplanan kalabalığa kamyonla giren bir terörist 86 kişiyi öldürmüştür.

13 Kasım 2015 akşamında Fransa Stadyumu hedef alınmış, Paris'in çeşitli sokaklarında ve bir konser alanında terör saldırıları gerçekleştirilmiştir. Petit Cambodge ve Le Carilllon silahlı saldırıları, Bataclan Tiyatrosunu ablukaya alma, Fransa Stadyumu patlaması, La Casa Nostra'da ve Rue de Charonne'de silahlı saldırılar olmak üzere eş zamanlı 5 terör saldırısı meydana gelmiştir (Maulny, 2017:18). Bu çalışmada, 5 eş zamanlı saldırı 13 Kasım Saldırıları olarak yer almaktadır. Saldırıların amacı mümkün oldukça daha fazla insana zarar vermektir ve bu saldırılarda sembolik değerleri yüksek olan yerlerin hedef alındığı görülmektedir. (Colijn, vd., 2015:2). Bu eş zamanlı saldırılar sonucunda 130 kişi hayatını kaybetmiş ve 368 kişi yaralanmıştır. Charlie Hebdo saldırısı sonrasında çok uzun bir süre geçmeden gerçekleşen bu saldırılara cevaben, Paris savaş uçaklarını havalandırmada tereddüt etmemiştir. Fransa'nın terörle savaşı üç aylık bir olağanüstü hâl ilanından sonra, Cumhurbaşkanı Hollande'in Fransa'nın bir savaş başlatacağını söyleyip Irak ve Suriye'ye yönelik askeri kampanyasını hızlandırmasıyla başlamıştır (Murphy, 2016). İkinci Dünya Savaşı'ndan sonra ilk defa tüm ülkeyi kapsayan olağanüstü hâl ilan edilmiştir.

$\mathrm{Bu}$ çalışmada, El Kaide ve IŞi̇D tarafından yapılan terör saldırıları sonrasında geliştirilen iki farklı terörle savaş yaklaşımının analiz edilmesi amaçlanmıştır. İslam topraklarında İslami bir yönetim- hilafet- kurma amacıyla hareket eden bir terör örgütü olan El Kaide, 1988 yılında Afganistan'da kurulmuştur. El Kaide 1988 yılında Kenya ve Tanzanya'da ABD büyükelçiliklerine saldırarak 224 kişinin, 2000 y1lında Yemen'deki ABD USS Cole'de bir Amerikan askeri gemisine bir saldırı gerçekleştirerek 39 kişinin ölümüne neden olmuştur (Rosenau ve Powell, 2017:3). El Kaide'nin temel amaçlarından birisi Orta Doğu'daki dış müdahaleri bitirme ve İslam devriminin Müslüman ülkelerde yayılmasıdır (ADL, 2020). Körfez Savaşı sonrası, Müslümanların kutsal toprakları olan Suudi Arabistan'daki Mekke ve Medine'deki mevcut ABD askerlerinin varlığını bitirme amacı güden örgütün kurucu lideri Usame Bin Ladin, Suudi yöneticilere karşı geniş bir terör kampanyası başlatmıştır. Suudi ailesini devirme ve İslami bir rejim oluşturma amacı taşımıştır. 1990 yılında Irak'ın Kuveyt'i işgali El Kaide açısından önemli bir dönüm noktası olmştur. Irak'ın Kuveyt'ten çıkarılması için ABD’nin askerlerinin Suudi Arabistan'dan çıkarılmasını istemiş, Suudi Arabistan yönetimi, Ladin ve takipçileri tarafından işgalin kolaylaştırıcı olarak suçlanmıştır (Rollins, 2011:6). Bin Ladin'in Amerikan karşıtlığı 1996 sonrası tırmanmış ve Müslümanlar ve $\mathrm{ABD}$ arasında savaşın başladığı söylemini kullanmıştır. El Kaide, işgalci ABD’nin durdurulmasının dünyadaki tüm müslümanların görevi olduğunu dile getirmiştir (ADL, 2020). 1998'de tüm Müslümanlara seslenerek ABD'lileri öldürmeleri için iki fetva yayınlamıştır. El Kaide'nin Kenya ve Tanzanya'daki büyükelçilikleri bombalaması bu fetvalardan sonra olmuştur (Thomas 2018:2). Bin Ladin 2011 yılında öldürülmüş ve ölümünden sonra örgüt yönetim açısından sıkıntıya düşmüştür (Lee, 2015:17).

Diğer taraftan, IŞSiD (ISIS) 2014 yılında Ebu Bakr elBağdadi tarafından kurulmuştur. 2003 yılında ABD'nin Irak'a müdahalesi ve 2011 yılında ABD'nin bölgeden ayrılışının bir yan ürünü olarak tanımlanmaktadır (Jones, vd., 2017:x). 2017 yılında Pew tarafindan yapılan bir araştırmada dünyanın karşılaştığı en büyük terörist tehdit olarak görülmüştür (Jasko, vd., 2018:3). IŞİD 2014 yılında askerî açıdan başarılı bir dönem geçirmiş, Irak ve Suriye'de Belçika büyüklüğünde bir toprağı ele geçirip kontrol etmeyi başarmıştır (Jasko, vd., 2018:3). 2017 yılında örgüt gücünü kaybederken bile yaklaşık 2,5 milyon insanı yaşadığı alanı fiili olarak kontrol edebilmiştir (Jones vd.,2017: ix) ${ }^{2}$.

Dünyanın çeşitli yerlerinde terör saldırısı yapan bu iki örgütün birbirlerine benzedikleri ve birbirlerinden ayrıştıkları yönleri bulunmaktadır. İki örgütün birbirine benzediği ilk özelliği iki örgütünde selefi-cihatçı ideolojiyi benimsemesidir. Her iki örgütte Müslümanları selefi bir devleti takip etmeleri için çalışmaktadır (Wright, vd., 20162017:7). Selefilik inanc1, Muhammed Ibn al-Wahhab (1703-1792)'e kadar giden ve İslam'ın ilk zamanlarına geri dönerek, dini herhangi bir yenilikten arındırma amacı taşımaktadır (Willem ve Bloem, 2017:9). Her iki örgütte, devlet ve dinin şeriat kurallarına göre yönetilmesi için çalışmaktadır (Jasko, vd., 2018:12). El Kaide ve IŞİD

2 2014-2017 arasında, IŞİD Irak ve Suriye'de 3 ile 12 milyon arası bir nüfusa etki etmeyi başarmış (Jones, vd., 2017: ix). 
halifelik konusunda tartışmalı olsa da şeriat yönetimini ve pozitif hukuka karşı olmaları konusunda birleşmiş durumdadırlar (Revkin, 2016:8). Diğer taraftan, şeriat kurallarındaki ortak amaçla birlikte, IŞİ, El Kaide ile kıyaslandığında, tekfir, hilafet ve ahir zaman anlatıları üzerine odaklanmıştır (Jasko, vd., 2018:13). IŞID, öncelikli olarak ulusötesi bir halifeliğin kurulmasını amaçlamakta ve yerel bir başlangıç olarak Suriye ve Irak topraklarında siyasi bir oluşumla başlama gayesi taşımaktadır. IŞiD üyelerinin büyük kısmı, Müslümanları kafirlere karşı koruyup ve kafirleri yenecek mehdi anlayışını paylaşmaktadır (Gomes ve Mikhael, 2018:19).

İki örgütün birbirlerinden uzaklaştığı diğer bir özellik, IŞİD'ın belirli bir toprağın kontrolünü sağlayarak siyasi düzen inşa etme çabasına odaklanırken, El Kaide'nin terörü bireyleri belirli davranışlara teşvik için kullanarak güç dengesi kurmaya çalışmasıdır (Gomes ve Michael, 2018:3). Dünyanın gördüğü en vahşi terör örgütlerinden birisi olarak görülen IŞİD, sosyal medyayı ve teknolojiyi farklı amaçlar için kullanmaktadır. 2015 yılında, IŞİD'ın 40,000'den fazla twitter hesabı bulunmaktaydı (Jones, vd., 2017:181). IŞİD sosyal medyayı, düşmanlarını infaz ederken, kurbanlarını canlı canlı yakarken ve baş kesme videolarını paylaşarak yayınlamak için kullanarak korku salma amac taşımıştır (Jones, vd., 2017:178). IŞİD, ayrıca bu bu kurbanlarını öldürdükleri profesyonel çekimli videolorı örgüte insan kaynağı sağlamada bir araç olarak kullanmıştır (Jones, vd., 2017:175). Büyük çoğunluğu batı ülkelerindeki göçmen asıllı vatandaşları Suriye ve Irak'a gelerek IŞID’a katılmaya ikna etmede büyük bir başarı yakalamış ve kısa sürede askerî açıdan gerekli insan kaynağını elde etmede muvaffak olmuşturlar. 2015 yılı sonunda, Irak ve Suriye'ye 86 ülkeden 30,000'i aşkın bireyin IŞİD'a katıldığ 1 tahmin edilmektedir (Jasko vd, 2018:12-13). Ayrıca IŞİD çeşitli terör örgütlerinden de destek alarak güçlenme evresinde desteğini artırmıştır (Blanchard ve Humud, 2018) IŞSiD toprak elde etmeye devam ettikçe, Asya, Orta Doğu, Afrika, Avrupa ve Kuzey Amerika'da binlerce kişiyi etkilemeye devam etmiştir (Jones vd., 2017:1). IŞID yabancı savaşçıları etkin bir şekillde kullanmıştır. 2017 yılında yaklaşıl 40000 yabancı savaşçı bulunmaktaydı Suriye ve Irak'ta (Jones vd, 2017:176): Avrupa'dan 6000 savaşçı Irak ve Suriye'ye geldiği düşünülünce Batılı devletlerin yabancı savaşçılar ve yerli terörizmle ilgili problemi gözler önüne serilebilir.

İki örgüt arasındaki temel farklardan birisi halk desteğini kazanma konusundaki strateji farklılıklarıdır (Wright, vd., 2016-2017:6). IŞID küresel bir topluma hitap etmeye çalışırken, yerel nüfusu zorlamaktadır: Rusya, Fransa ve başka yerlerdeki Müslümanlara yönelik farklı dillerde yayın yaparak potansiyel askerlere yönelik propaganda yapmaktadır (Wright vd., 2016-2017:6). Bununla birlikte, IŞİD ya bizimlesiniz ya da kafirsiniz gibi katı bir tutum sergileyerek zorlayıcı taktikleri benimsemiştir. Diğer taraftan El Kaide, yerel unsurlarla hareket etme eğilimindedir (Wright, vd., 2016-2017). Bu durum, kendisini IŞİD'ın Suriye'deki acımasız yönetiminde ve El Kaide'nin yerel milislerle ittifaka dayalı yapısında görülebilir (Wright, vd., 2016-2017:6-8). Böylelikle El Kaide'nin siyasi hedefini köktenci Müslüman tasvirlerinin siyasi ve ideolojik yönelimleri görülmektedir (Gomes ve
Mikhael, 2018:18). Bu terör örgütleri, Müslüman dünyasını Batı'ya karşı koruma ve bu doğrultuda, ABD’ye karşı çabaları yoğunlaştırma gayesi taşımaktadırlar. Özetle, IŞİD siyasi hedefleri olan aşırılık yanlısı bir hareketken, El Kaide günümüzde aşırılık yanlısı inançlara sahip bir siyasi organizasyondur (Wright, vd., 2016-2017:8).

ABD Taliban rejiminin El Kaideye destek vermesinden dolayı Afganistan'a askeri müdahalede bulunurken, aynı zamanda Taliban rejiminin cihatçı yapısına karşı da müdahale etmiş bulunuyordu (Bymann, 2011). 11 Eylül saldırılarının ardındaki teröristlerin 19'uzundan 15'i Suudi vatandaşı olsa da (CIA, 2002), Suudi Arabistan'1n saldırılarla ilişkisi olmaması ve aynı zamanda Taliban rejiminin El Kaide'ye desteği Suud yönetimi için geçerli değildi. Bu yüzden, El Kaide ve Taliban arasındaki ilişki ve ABD’nin ulusal çıkarları Afganistan'a müdahale edilmesine neden olmuştur (Cottey, 2003:171).

Fransa, 13 Kasım saldırılarının sorumluluğunu üstlenen IŞİD'ın hedeflerini vurmak için fazla beklememiş ve Rakka'ya havadan müdahale etmiştir. Neden askeri müdahale yapılmıştır sorusuna gelindiğinde, 5 eş zamanlı saldırı, Fransa için önemli bir meydan okuma olarak değerlendirilmiş ve can kaybının yüksek olması saldırılara ciddi bir karş1lık verilmesi gerekliliğini doğurmuştur. Diğer taraftan saldırganların durumu da dikkat çekicidir. Saldırganların tamamının Fransız vatandaşı olması ve 8 'inin Suriye'den dönen yabancı askerler olması Rakka'ya askeri müdahale yapılmasına etki etmiştir (Brisard, 2015). Ayrıca, IŞiD 2013'ten 2015'e kadar defalarca Fransa'yı hedef alması ve yabancı savaşçıların saldırılarındaki artış Fransa'nın 13 Kasım saldırıları sonrasında IŞİD'a askeri olarak müdahale etmesine yol açan etkenlerdendir (Brisard, 2015).

El Kaide'nin ABD topraklarında saldırıları gerçekleştirmesi, örgütün temel amacının bir parçası olarak değerlendirilebilir. El Kaide tarafindan, Kenya ve Tanzanya'daki Amerikan büyük elçilikleri 1998 yılında saldırıya uğramış, 2000 yılında Yemen'deki Askeri üst bombalanmıştı. Bu saldırılardan 3 yıl sonra gerçekleştirilen 11 Eylül saldırılarının sorumluluğunu Bin Ladin 2004'te bir video yayınlayarak kabul etmişti. Yayınlanan videonun dikte edilmiş versiyonunda Manhattan halkının savaşı önlemesinin bir yolu olduğu hakkında uyararak başlamaktadır. Bin Ladin İsveç yerine neden ABD'nin hedef alındığını düşünülmesi istemektedir (Bin Ladin, 2004). Ayrıca, Bin Ladin, bağımsızlık için savaşan, baskı altında yaşayamayan insanlar olduğunu, milletlerinin özgürlüğü verilmeden bu savaşın bitmeyeceğini dile getirmiştir (Bin Ladin, 2004). Saldırıların gerçek nedeninin aslında güvenlik arayışı olduğunu ve Lübnan'da yaşanan zulümlerden dolayı misilleme yapıldığını belirtmiştir (Bin Ladin 2004). Diğer taraftan, IŞİD'ın Fransa'yı hedef almasının ardında Fransa'nın Suriye iç savaşındaki pozisyonu ve Hz. Muhammet'e karşı yapılan hakaretin etkisi bulunmaktadır (Daniel, 2015:3). IŞİD, saldırılar sonrası Arapça, Fransa ve İngilizce olarak yayınlanan mesajda, Fransa'nın yolunu izleyen devletleri de uyarmıştır (Daniel 2015:4). Sonuçta, Fransa'nın Ortadoğu politikası IŞID'ın Fransa'yı hedef almasının gerekçesi olarak sunulmuştur. 
Terör saldırılarının giderek daha fazla insanın canına mal olması terörle mücadele yöntemlerinin analizini önemli bir çalışma alanı haline getirmektedir. Terörle mücadelede uygulanan yaklaşımlardan "terörle savaş" ise politika şekillendirici etkisiyle dikkat çekmektedir.

\subsection{Araştırma Modeli}

Bu çalışmada nitel analiz yöntemi kullanılmıştır. Amaçlı örneklem tekniği, çalışmanın irdelediği konu hakkında zengin bir bilgi sunabilme durumu yüksek olduğu düşünülen örneklerin tercih edilmesidir (Yıldırım \& Şimsek, 2005). Bu teknik derinlemesine analiz yapmaya imkânı sunmasından dolayı tercih edilmiştir. Amaçlı örneklem tekniği kullanılarak, terör saldırılarının ardından iki devlet liderinin yaptığı konuşmaların metinleri içerik analizi yöntemiyle incelenmiştir. İçerik analizi yöntemi yazılı metinlerin içerdikleri mesajların özetlenmesi imkanını sağlarken bu mesajların sistematik bir şekilde belirtilmesine olanak tanımaktadır (Cohen, Manion \& Morrison, 2007; Akratan: Sert, vd., 2012:353).

Devlet liderlerinin diş politikadan sorumlu olmalarından dolayı analiz için onların konuşma metinleri tercih edilmiştir (Gershkoff \& Kushner, 2005). Bu doğrultuda, 11 Eylül Saldırılarından sonra, ABD başkanı George W. Bush 16 Eylül 2001'de ulusa sesleniş konuşması ve 13 Kasım saldırılarından sonra Fransa Cumhurbaşkanı François Hollande'in 16 Kasim 2015'te Parlamento'nun ortak toplantısında yaptığı konuşma metinlerinin içerik analizi tekniği kullanılarak analiz edilmiştir. Önce konuşma metinleri temalara ayrılarak, alt kategoriler belirlenmiş ve betimsel analiz tekniği uygulanmıştır. Bu teknikle birlikle, araştırmanın iç geçerliliğinin artırılması hedeflenmiştir (Günbay1, 2019). Betimsel analiz konuşma metinlerinden doğrudan alıntılar yapılarak derinlemesine analiz yapılmasına olanak tanımaktadır (Günbayı, 2019). Sadece iki liderin terör saldırıları sonrasında yaptığı iki konuşma metninin nitel analiz yöntemiyle irdelenmesi çalışmanın genellenebilirliği açısından çalışmanın limitini oluşturmaktadır. Diğer taraftan, sadece iki konuşma metninin derinlemesine analiz yapılmasını imkân tanıyan bu yöntemle birlikte terörle savaş yaklaşımının analizinde kapsamın geliştirilmesi ve sı ̆ bir anlatımdan kaçınılması hedeflenmiştir. Ayrıca, sadece iki metnin incelenmesi, derinlemesine bir analiz yapılma imkânı sağlamış ve bu iki metnin detaylı incelenmesine olanak tanımıştır.

\subsection{Verilerin Analizi}

Çalışmada, öncelikle ABD Başkan Bush ve Fransa Cumhurbaşkanı Hollande'in konuşma metinleri için içerik analizi yöntemiyle, 5 tema belirlenerek, bu temalara dair kategoriler oluşturulmuştur. İki liderin terörle savaş yaklaşımları; devletin ve ulusun gücü, düşmanın kapasitesi ve kötülüğü, askeri ve idari düzenlemeler ve uluslararası iş birliği olarak 5 tema belirlenmiştir. Daha sonra betimsel analiz tema analizin devamı olarak kullanılmış ve iki liderin konuşma metinlerinden doğrudan alıntılar yapılarak öncelikle yorum yapılmadan verilmiş ve araştırmanın iç geçerliliğinin artıracak şekilde temaya ilişskin betimlemeler yapılması tercih edilmiştir (Günbayı, 2019). Böyelikle ilk aşamada temalar belirlendikten sonra, betimsel analiz yapılmış ve metinler analiz edildikten sonra iki liderin terörle savaş yaklaşımı karşılaştırmalı olarak analiz edilmiştir.

Her bir tema sınıflandırılarak aşağıda belirtilen alt kategoriler oluşturulmuştur:

- Terörle Savaş Teması ve Kategoriler: Karşılık Verme, Saldırılarda Savaş Eylemlerinin Uygulanması, Savaşta Olma, Özgürlüğün Tehdit Edilmesi, Terörle Savaşın Kapsamlı Olacağı,

- Devletin ve Ulusun Gücü Teması ve Kategoriler: Kurumlara Güven Duyma, Vatandaşlara Güven Duyma ve Kaynak Kullanma,

- Düşmanın Kapasitesi ve Kötülü̆ğ̈̈ Teması ve Kategoriler: Düşmanı Tanımlama, Yerli Terörist Vurgusu, Düşmanın Herkese Zarar Vermesi, İslam'la değil Cihatçı İslam'a Karşı Mücadele Medeniyet Savaşı, Müslüman Ülkelere Sorumluluk Verme,

- Uluslararası İş Birliği Teması ve Kategoriler: Teröre Destek Veren ve Karşısında Olanlar Ülkeler Ayrımı, Saldırıların Sadece Bir Ülkeye Karşı Olmadığg İnanc1, Diğer Devletlerden Destek Bekleme, Uluslararası Kurumlara Güvenme,

- Askeri ve İdari Düzenlemeler Temast ve Kategoriler: Ulusal Güvenlik Unsurlarını Güçlendirme, Yeni İdari Düzenlemeler Yapma, İstihbaratı Güçlendirme.

Analiz sonucunda, iki liderin terörle mücadelede 'terörle savaş' yaklaşımını savunurken benzer gerekçelendirmelere dayandıkları tespit edilmiştir.

\subsection{Araştırma Soruları}

Terör örgütleri tarafından yapılan saldırılar siyasi aktörleri terörle mücadele yaklaşımları geliştirmeye zorlamaktadır. Bazı liderler terörle mücadele politikalarını devlet kapasitesi, terör saldırılarının etkisi (ölü/yaralı sayısı), düşmanın kapasitesi ve saldırıların sıklığı vb. durumları göz önüne alarak terörle mücadele stratejileri benimsemektedirler. 11 Eylül saldırıları, El Kaide tarafından yapılmış, ülkenin sembolik öneme olan yapı ve kurumlar hedef alınmış, binlerce kişinin canına mal olmuş ve örgüt tarafindan ABD'ye yönelik birçok saldırı gerçekleştirilmiştir. ABD saldırıların ardından terörle savaş yaklaşımını tercih ettiğini açıklamış ve Afganistan'a askeri müdahelede bulunmuştur. Diğer taraftan, 13 Kasım 2015'te Paris'in beş farklı alanında bombalar patlamış, IŞİD'ın bu saldırıları 129 kişinin hayatını kaybetmesine yol açmıştır. $\mathrm{Bu}$ saldırılardan kısa bir süre önce de IŞİD'ın Paris’te birçok saldırısı olmuştur. 13 Kasım saldırıları sonrası Rakka'ya koalisyon güçleriyle bir askeri müdahale gerçekleştirmiştir. Hollande saldırılara cevaben Fransa'nın savaşta olduğunu ve terörle mücadelede, aynı yaklaşımı tercih ettiğini ilan etmiştir. Bu iki ülkenin terör saldırıları sonrası başlattıkları terörle savaş stratejinin neden farklı veya benzer terörle savaş yaklaşımı gerçekleştirdikleri araştırılmaktadır. $\mathrm{Bu}$ doğrultuda, çalışmanın araştırma soruları aşağıda belirtildiği gibidir:

1) Terörle savaş yaklaşımının çerçevesi nedir?

2) ABD ve Fransa'nın terörle savaş yaklaşımı doğrultusunda gerçekleştirdikleri askeri operasyonlar nelerdir? 
3) ABD başkanı George W. Bush ve Fransa Cumhurbaşkanı François Hollande'in terör saldırıları sonrasında benimsedikleri terörle savaş yaklaşımı hangi açılardan benzerlikler ve farklıliklar sergilemektedir?

\section{Terörle Mücadelede 'Terörle Savaş' Yaklaşımı}

Terörle savaş yaklaşımı temelde terörle mücadelede askeri gücün kullanılmasıdır. Tanımsal olarak: "Terörle savaş, 11 Eylül 2001'deki terör saldırllarına yanıt olarak başlatılan Amerikan liderliğindeki küresel terörle mücadele kampanyasını tanımlamak için kullanılan bir terimi ifade etmektedir" (Encyclopaedia Britannica, Inc., 2020). Terörle savaş yaklaşımının ideolojik bir yanı olduğunu belirten Beshara (2018:86), bu yaklaşımı küresel toplumun geniş kesimlerinde ABD'nin küresel hegemonyasını korumak ve genişletmek için etkili bir şekilde meşrulaştırıcı bir strateji olarak tanımlamaktadır. Terörle savaş yaklaşımı terörün güvenlik merkezli olarak düşünülmesinin ötesinde uluslararası düzeyde bir çabada gerektirmektedir. Özellikle 11 Eylül saldırıları, ulusal güvenlik kapsamında uygulanan politikaları ifade etmek için kullanılmakta kalmamış ayrıca, terörle mücadelede Irak'a yönelik yapılan askeri müdahale için gerekli çerçeveyi de sağlamıştır (Reese \& Lewis, 2009:777). Terörle savaş yaklaşımı ayrıca Ortadoğu'da ABD askeri gücünü konuşlandırma ve demokrasiyi geliştirme gibi amaçları içermektedir (Gordon, 2007:53).

Terörle savaş yaklaşımı, terör saldırılarından sonra askeri güçlerin kullanılmasının meşru bir söylemi olarak değerlendirilmektedir.

\begin{abstract}
"Terörle savaş" dilinin sadece politika tartışmalarının, terörizm ve terörle mücadele gerçeklerinin tarafsız veya nesnel bir yansıması olmadı̆̆ını; daha ziyade, savaşın makul, sorumlu ve doğal olarak "iyi” görünmesini sağlamak için özel olarak tasarlanmış çok dikkatli ve kasıtlı olarak oluşturulmuş bir kamu söylemidir" (Jackson, 2005:147).
\end{abstract}

Böylelikle, bir terör saldırısının ardından, askeri operasyonların yapılmasi ve desteklenmesi gerçekleşebilmektedir. Bu doğrultuda, 13 Kasım saldırıları sonrasında Fransız jetleri Suriye'ye havalanmış ve askeri operasyon gerçekleştirmiştir (France24, 2015), saldırı sonrasında Hollande, bu terörist ordusunun mümkün olan en fazla zararı verecek şekilde operasyon yapılacağını açıklamıştır.

Terörizmin ulusal ve uluslararası politikayı etkilediğinin en önemli göstergelerinden birisi 11 Eylül saldırıları sonrasında terörle savaş yaklaşımı olmuştur. Uçakların kitle imha silhaları halini almasıyla yeni riskleri ortaya çıkması ABD'yi yeni bir yaklaşıma sevk etmiştir (Daalder \& Lindsay, 2001:1). Sonrasında, Bush yönetimi, 'terörle savaş' yaklaşımını ABD'nin dış politikasını ve ulusal savunma politikasının merkezine taşımıştır. 11 Eylül saldırıları sonrasında Beyaz Saray tarafından 2003 yılında yayınlanan Terörizmle Müdacale Ulusal Stratejisinde bu durum açıkça görülmektedir: "11 Eylül'den bu yana yakalanan ivmeyi sürdürmek ve terörizme karşı küresel savaşı ön planda tutmak için ABD Hükümeti'nin tüm kurumlarl ve ajanslarl, ikili ve çok tarafl müzakereler için standart bir gündem maddesi olarak terörle mücadele etmeyi teşvik edecektir" (White House, 2003:19). Terör saldırıları sonrası devletin kurum ve kuruluşları bu mücadele için seferber edilebilmektedir.

Nihayetinde terörle savaş yaklaşımı Irak'ın işgali için gerekli retorik altyapıyı sunmada yardımcı olmuş (Reese \& Lewsi, 2009:779) 11 Eylül ile Irak'ın işgali bağlantı kurularak ABD'nin Irak Stratejisini büyük oranda şekillendirmiştir. Amerikan halkı El Kaide ve Saddam Hüseyin arasında bağlantı olduğuna inanmış ve kamuoyunun dörtte üçü savaşı desteklemiştir (Gershkoff \& Kushner, 2005:525).

Diğer taraftan, terörle savaş yaklaşımları çeşitlilik göstermektedir. Örneğin Çin Halk Cumhuriyeti, Sincan Uygur Özerk Bölgesinde İslamcı terörizmle mücadele kapsamında yerel toplumu ve kurumları yeniden şekillendiren, askeri ve sivil bir kampanya şeklinde devam etmektedir (Wayne, 2009:249). Ayrılıkçı teröristler ve aşırılıkçı İslamcılar olarak görülen Müslüman Uygurlara yönelik olarak kapsamlı bir terörle mücadele yaklaşımı geliştirilmiş: yeniden eğitim kamplarından, dini ve etnik sembollerin kullanımının kontrol edilmesine kadar çeşitli unsurları içeren bir yaklaşım benimsenerek terör ve entegrasyon politikaları terörle savaş yaklaşımıyla birleştirilerek sert önlem ve askeri kontrole dayalı bir sistem geliştirilmiştir. Terörle mücadele yaklaşımı olarak terörle savaş İngiltere'de olduğu gibi mahkumlara yapılan kötü muamelelere mazeret olarak kullanılabilmektedir (Blakeley, 2017). Terörle savaş yaklaşımı, terörle mücadelede uygulanan yöntemlere altyapı hazırlayabilmektedir.

Terörle savaş yaklaşımında kullanılan yöntemlerde büyük bir çeşitlilik arz etmektedir. Terör savaş yaklaşımının askeri boyutu ve siyasi boyutu olan bir yapilanması mevcuttur. Örneğin ABD'nin 11 Eylül sonrası terörle savaş yaklaşımı Afganistan ve Irak'ta fiili savaşları, açık ve gizli askeri operasyonları (Daalder \& Lindsay, 2001) ve askeri yardım programlarını içermekle kalmayıp, ulusal boyutta resmi kurumların düzenlenmesini, Ulusal Güvenlik birimi gibi yeni yapılanmaları, ABD Vatanseverlik Kanunu gibi yasal değişimleri, Guantanomo Hapishanesi gibi yeni hapishane düzenlemelerini içermektedir (Encyclopaedia Britannica, 2020).

Diğer taraftan, terörle savaş yaklaşımının kapsamlı bir sivil yanı bulunmaktadır. Terörle savaş yaklaşımı, özellikle diplomasi ve finansman alanında ayrıntılı düzenlemeler ve uluslararası iş birliğine dayalı bir dayanışma oluşturma çabasını da içermektedir. Diplomasi terörle savaş yaklaşımının, askeri yöntemlerle birlikte önemli bir bileşeni oluşturmaktadır. Örneğin, diplomatik çabalara Başkan Bush'un terörizmle mücadelede dünya çapında bir koalisyon kurma girişimleri gösterilebilir. 136 ülke tarafından ABD'ye yardım teklif edilmiştir ve 46 çok taraflı kuruluş desteklerini beyan etmiştir (U.S. Department of State Archive, 2009). Görüldüğü gibi terörle savaş yaklaşımı diplomatik oluşumlarla birlikte yürütülmekte ve diplomasi bir araç olarak kullanılmaktadır. "Mücadelenin çoğu diplomatik bask yoluyla gerçekleştirilecek; ekonomik, mali ve politik yaptırımlar; istihbarat ve kolluk kuvvetleri iş birliği” gündemdedir (Daalder \& Lindsay, 2001:2). 
Diplomasi ayağı olmadan sadece askeri düzenleme ve faaliyetler yeterli olmayacaktır.

Paris, 13 Kasım Saldırılarının ardından terörle savaş yaklaşımını askeri alana ağırlık vermekle birlikte (Samaan \& Jacobs, 2018) diplomatik, finansal kaynakların kontrolü ve uluslararası hukuk çerçevesinde uygulamıştır. Fransa terörle mücadelede, özellikle terörün finansmanı konusunun üzerinde durmaktadır. Fransız Maliye Bakanı Sapim, saldırı sonrasında, terörle mücadelenin en etkin yollarından birisinin terörün finansmanının engellenmesi olduğunu açıklamıştır (Chalkiadaki, 2015:30). Finasman kaynaklarının kesilmesi terörle savaşın önemli bir faktörü olarak değerlendirilmektedir. Diğer taraftan, terörle savaş yaklaşımının Paris açısından dış politika üzerinde yönelendirici etkisi olmuştur.13 Kasım saldırılarından sonra dış politikada değişim talepleri gündeme gelmiştir. Aşırı sağcı Ulusal Cephe'nin temel üç politikası çeşitli zümrelerce dile getirilmeye başlanmıştır: sınır kontrolünün iyileştirilmesi, radikal İslamcı gruplarla ilişkisi olan çifte vatandaşları vatandaşlıktan çıkarma ve selefi camileri kapatma (Colijn, vd., 2015:5). Sonuç olarak terörle savaş yaklaşımı daha otoriter uygulamaları gündeme getirmekte ve insan hakları ile ilgili tartışmaları körüklemektedir.

\subsection{Askeri Operasyonlar}

11 Eylül sanrası ABD bir dizi yurtdıșı askeri operasyonlar gerçekleştirmiştir. 7 Ekim 2001'de başlayan Kalıcı Özgürlük Operasyonu, İngiltere, Avusturya ve Japonya gibi farklı birçok ülkenin desteğini almış ve 11 eğitim kampı ve 29 komuta ve kontrol merkezi imha edilmiş ve operasyon sonucunda Taliban yönetimi birçok büyük şehri teslim etmiştir (U.S. Department of State Archive, 2009). Bir ay kadar süren bu operasyon küresel boyuta erişmiştir. Afganistan'da gerçekleşen bu operasyon Afrika Boyunuzu ve Trans Sahara gibi dünyanın diğer bölgelerinde gerçekleştirilen operasyonlarla desteklendi (Post 9/11 Major Military Operations, 2020). Böylelikle, ABD’nin terörle savaşı geniş bir coğrafyaya yayılmış ve küresel düzeyde gerçekleşmiştir.

Öncelikle, Fransa terörle mücadelede askeri olarak iki coğrafi bölgede aktif olarak müdahale etmektedir: Suriye ve Irak ve Sahel (Mignot-mahdavi, 2020:2-4). Diğer taraftan 13 Kasım saldırılarının ardından daha farklı bir durum gözler önüne serilmiştir. Rakka'ya düzenlenen operasyonda, IŞID'ın komuta merkezi bombalanmış ve Fransa için tehdit olabilecek 40 cihatçı askeri müdahalede hedef alınmıştır (Maulny, 2017:24). Fransız askeri müdahalesi daha sonra IŞİD Karşıtı Koaliasyon birliklerine destekle sınırlı kalmış, Fransa'nın diğer bölgelerdeki, örneğin Mali müdahalesinin ${ }^{3}$ seviyesine ulaşamamıştır.

\section{Bulgular}

Terör saldırılarından sonra uygulanan terörle savaş yaklaşımının analiz edilebilmesi, karar verme sürecinde kilit rol oynayan siyasi liderlerin görüşlerini hesaba katılmasıyla mümkün olabilmektedir. Bu doğrultuda, ABD ve Fransa'nın terör saldırıları sonrasındaki iki liderin,

32013 yılında Mali'ye cihatçı grupları durdurmak için 4.000 Fransız askeri yerleştirilmiştir. saldırılardan sonra parlamento görüşmesi öncesi yaptıkları konuşma metinleri incelenmiştir. Başkan Bush 20 Eylül 2001'de Ulus'a seslenmiş ve 11 Eylül saldırılarına nasıl bir karşılık verileceğini açıklamıştır. Fransa Cumhurbaşkanı François Hollande 13 Kasım 2015 terör saldırılarının ardından Parlamento'nun ortak toplantısından önce yaptığı konuşma metni incelenmiştir.

Konuşma Bush ve Hollande'in metninde 5 tema belirlenmiştir: terörle savaş; devletin ve ulusun gücü, düşmanın kapasitesi ve kötülüğü, uluslararası iş birliği, askeri ve idari düzenlemeler. Her bir tema için çeşitli kategoriler oluşturularak analiz edilmiştir.

Tablo 1. Terörle Savaş Yaklaşımına İlişkin Tema Analizi

\begin{tabular}{lcc}
\hline Temalar & George W. Bush & François Hollande \\
\hline Terörle Savaş & $\sqrt{ }$ & $\sqrt{ }$ \\
\hline $\begin{array}{l}\text { Devletin ve } \\
\text { Ulusun Gücü }\end{array}$ & $\sqrt{ }$ & \\
\hline $\begin{array}{l}\text { Düşmanın } \\
\text { Kapasitesi ve } \\
\text { Kötülüğü }\end{array}$ & $\sqrt{ }$ & $\sqrt{ }$ \\
\hline $\begin{array}{l}\text { Uluslararası } \\
\text { İş birliği }\end{array}$ & $\sqrt{ }$ & $\sqrt{ }$ \\
\hline $\begin{array}{l}\text { Askeri ve } \\
\text { İdari } \\
\text { Düzenlemeler }\end{array}$ & & \\
\hline
\end{tabular}

Yukarıda belirtilen beş temanın iki liderin konuşma metinlerinden yer aldığı görülmekle birlikte, çalışma kapsamında betimsel analiz yapıldığında, bahsi geçen temaların kategorileri incelenmiş farklılıklar tespit edilmiştir.

Terörle savaş teması için 5 kategori belirlenmiştir: Karşılık Verme, Saldırılarda Savaş Eylemlerinin Uygulanması, Savaşta Olma, Özgürlüğün Tehdit Edilmesi, Terörle Savaşın Kapsamlı Olacağı.

İki liderin konuşmalarındaki saldırganların neden kendi ülkelerini hedef aldıkları ve saldırılarla ilişkilendirme tarzları birbirlerine benzemektedir.

Tablo 2. Terörle Savaş Teması

\begin{tabular}{|c|c|c|}
\hline Kategoriler & George W. Bush & François Hollande \\
\hline $\begin{array}{l}\text { Karş1l1k } \\
\text { Verme }\end{array}$ & $\sqrt{ }$ & $\sqrt{ }$ \\
\hline $\begin{array}{l}\text { Saldırılarda } \\
\text { Savaş } \\
\text { Eylemlerinin } \\
\text { Uygulanması }\end{array}$ & $\sqrt{ }$ & $\sqrt{ }$ \\
\hline $\begin{array}{l}\text { Savaşta } \\
\text { Olma }\end{array}$ & $\sqrt{ }$ & $\sqrt{ }$ \\
\hline $\begin{array}{l}\text { Özgürlüğün } \\
\text { Tehdit } \\
\text { Edilmesi }\end{array}$ & $\sqrt{ }$ & $\mathrm{X}$ \\
\hline $\begin{array}{l}\text { Terörle } \\
\text { Savaşıı } \\
\text { Kapsamlı } \\
\text { Olacağı }\end{array}$ & $\sqrt{ }$ & $\mathrm{X}$ \\
\hline
\end{tabular}


Bush'un konuşmasında terörle savaş yaklaşımının dikkat çeken önemli unsurların başında terörle savaş teması gelmektedir. Bush kendi ülkesinde maruz kaldıkları savaş eylemlerine bir karşılık olarak ülkelerinin bir savaşta olduğunu belirtmiştir. Bush'in bu konudaki söylemi şu şekildedir: "Düşmanlarımızı adalete getirirsek ya da düşmanlara adaleti götürürsek fark etmez, adalet sağlanacaktır” (Bush,2001). Konuşma metninde, terör eylemleri savaş eylemleriyle eşdeğer olarak değerlendirilmiştir. Bush terör eylemlerinin savaş eylemi olduğunu şu şekilde dile getirmektedir: "11 Eylül'de özgürlük düşmanlarl ülkemize karşı bir savaş gerçekleştirdi. Amerikalılar savaşları biliyorlardı... yabancı topraklarda gerçekleşen savaşı biliyorlardı" (Bush, 2001). Dahası Bush, ABD'nin artık bir savaşta olduğunu belirtmiștir: "Ve bu gece hasarll Pentagon'dan birkaç mil uzakta, ordumuza bir mesajım var: Hazır ol" (Bush, 2001). Bu eylemlere karşılık verileceği ve özgürlüklerini tehdit eden düşmanlara karşı kapsamlı bir yaklaşım sergileneceği dile getirilmiştir: "Küresel erişimi olan her terörist grubu bulunana, durdurulana ve yenilgiye uğratılıncaya kadar bitmeyecek.” (Bush, 2001).

Diğer taraftan Hollande'in konuşmasında, Bush'un konuşmasına benzer şekilde terör saldırıları savaş eylemleri olarak değerlendirilmiştir. Bu durumu Hollande şöyle ifade etmektedir: "Fransa savaşta. Cuma akşamı Paris'te ve Fransa Stadı yakınlarında yapılan fiiller savaş eylemleridir. En az 129 ölü ve çok sayıda yaralı bıraktılar. Bunlar ülkemize, değerlerine, gençlerine ve yaşam tarzına karşı bir saldırganlık eylemidir" (Hollande, 2015). Savaş eylemlerine nasıl bir karşılık verileceği detaylı bir şekilde anlatılmıştır. Hollande bu durumu şöyle belirtmektedir: "Fransa Suriye'deki operasyonlarını hızlandıracak. Dün Rakka'daki IŞID kalesine hava saldırıları başlatmak için 10 Fransız savaş uçağına talimat verdim. Bir komuta merkezini ve bir eğitim kampını yok ettiler... önümüzdeki haftalarda bu saldırlara devam edeceğimizi duyurmak istiyorum. Perşembe günü, Charles de Gaulle uçak gemisi Doğu Akdeniz'e hareket etme kapasitemizi üçe katlayacak" (Hollande, 2015).

Terörle savaş yaklaşımının tercih edilmesi, Amerikalıların özgürlüğünün tehdit altında olmasından kaynaklanmaktadır. Bush'a göre “Tüm bunlar tek bir günde ve gecede gerçekleşti, özgürlüğün saldırı altında olduğu farklı bir dünya şimdi" (Bush, 2001). Böylelikle, metindeki terörle savaş temasının merkezinde Amerikan vatandaşlarının özgürlüğüne müdahale eden düşman kategorisi üzerine inşa edilmiştir. Saldırıları yapanlar özgürlük düşmanları olarak tanımlanmış ve özgürlüğün bir gecede tehdit altına alındığı belirtilmiştir. Hollande'in konuşmasının Bush'la farklılık taşıyan önemli bir unsuru Bush'un özgürlüğün tehdit altında değerlendirilmesi olmasına rağmen, Hollande Fransız kültür ve yaşam stilinin hedef alındığını vurgulamasıdır: “cuma günü, teröristlerin hedefi bir bütün olarak Fransa'ydl. Yaşam, kültür, spor, kutlamalara değer veren Fransa" (Hollande, 2015) Hollande'e göre Fransa bir bütün olarak hedef alınmıştır. İki liderin konuşmasındaki diğer bir farklılıksa, Hollande'ın konuşmasında terörle savaşın kapsamı hakkında net bir ifade olmamasıdır: "Birkaç yıl önce başlayan bu savaşta hepimiz zamana ihtiyacımız olduğunun farkındayı ve bu sabır, savaşacă̆ımı dayanıklılık ve şiddet gibi gerekli",
(Hollande, 2015). Bush konuşmasında terörle savaş yaklaşımı hakkında kapsamlı bir anlatımı tercih etmiştir.

$\mathrm{Bu}$ iki liderin konuşmasındaki diğer önemli benzerlik terörle savaşın kısa sürede bitmeyeceği uyarısıdır. Özellikle Bush terörle savaşın her terörist grubun yenilgiye uğratılana kadar devam edeceği ve küresel boyutta süreceğine dikkat çekmiştir. Diğer taraftan, Hollande terörle mücadelenin uzun süreceğine olan vurgusu ve bu mücadelenin sabır gerektiren zorlu bir süreç olacağı hakkında uyarısı dikkat çekici olmakla birlikte kapsamı hakkında ipucu vermemektedir.

Konuşma metinlerinden iki lider için belirlenen 2. tema ise devletin ve ulusun gücüne olan vurgudur. İkinci tema için 3 kategori belirlenmiştir: kurumlara duyulan güven, vatandaşlara güven ve kaynak kullanma.

Tablo 3. Devletin ve Ulusun Gücü Teması

\begin{tabular}{lcc}
\hline Kategoriler & George W. Bush & François Hollande \\
\hline Kurumlara & $\sqrt{ }$ & \multicolumn{2}{c}{} \\
Güven & & \\
Duyma & $\sqrt{ }$ & \\
\hline Vatandaşlara & $\sqrt{ }$ & \\
Güven & & $\sqrt{ }$ \\
Duyma & $\sqrt{ }$ & \\
\hline Kaynak & $\sqrt{ }$ & \\
Kullanma & & \\
\hline
\end{tabular}

İki liderin konuşmalarında oluşturdukları devletin ve ulusun gücü teması dikkat çekicidir. İki liderde, devletin kurum ve vatandaşlarıyla bu savaşın içinde olacağı ve terörle savaşta gerekli kaynakların sağlanacağını belirtilmektedir. Bush durumu şöyle ifade etmektedir: "Birliğimizin durumunu, tükenmenin ötesinde çalışan kurtarıcıların dayanıklılı̆̆ında gördük. -Sevgili yurttaşlarım, son dokuz gün boyunca, tüm dünya kendisi için birliğin durumunu ve gücünü gördü", (Bush, 2001). Diğer taraftan, Hollande: "Hükümet yetkililerinin düzenli işleyişi- ve bugün- kesintiye uğramadiğını kanıtlıyoruz. -Polis memurlarının, jandarmalarin, servis personelinin ve siz, ulusal temsilcilerimizin özverisine güvenebileceğimi biliyorum. Görevin ne anlama geldiğini ve gerektiğinde can feda etme ruhunu biliyorsunuz" (Hollande, 2015). Bu noktada, Fransa, Fransız vatandaşlarını yüceltme yolunu tercih ederken, ABD fedakâr Amerikalılıar ve özellikle askeri ve idari kurumların fedakarlıklarından bahsetmiştir.

Bush'un konuşmasında vatandaşlarla birlikte terör saldırıları sonrası müdahalede bulunan asker, itfaiye, sağlık çalışanları ve sivil vatandaşların yardımları öne çıkarmaktadır. Diğer taraftan, Hollande daha çok Fransız halkına olan inancını dile getirmekte ve terörle mücadelenin sivil unsurlardan destek aldığını vurgulamaktadır. $\mathrm{Bu}$ durumu şöyle ifade etmektedir: "Fransız halkı sadık, sert, cesur insanlar. Boyun ĕgmezler ve çocuklarından biri zarar gördüğ̈̈̈ne, karşılık verirler" (Hollande, 2015).

İki liderin konuşmasındaki diğer önemli bir farklılıksa Bush'un terörle savaşta çok yönlü bir yaklaşımı dile getirerek diplomasi, askeri ve finansal kaynakları belirtmesi: "Komutadaki her kaynağl- her diplomasi aracını, her istihbarat aracını, her kolluk kuvvetini, her 
finansal etkiyi ve gerekli her savaş silahını- küresel terör ă̆ının yok edilmesine ve yenilgisine yönlendireceğiz." (Bush, 2001). Hollande terörle savaşın finansal boyutunu ön plana çıkarmasıdır. "Tüm bu bütçe kararları, şu anda 2016 için tartışılan Finans Kanunu çerçevesinde alınacaktır. Mutlaka ekstra harcamaya neden olacaklar, ancak bu koşullar altında güvenlik paktının istikrar paktına öncelikli olacağına inanıyorum” (Hollande, 2015).

Konuşma metinlerinde analiz edilen 3. tema Düşmanın kapasitesi, acizliği ve kötülüğü temasıdır. Bu tema için 5 kategori belirlenmiştir: Düşmanı Tanımlama, Yerli Terörizm Vurgusu, Düşmanın Herkese Zarar Vermesi, Medeniyet Savaşı Anlayışı ve Müslüman Ülkelere Sorumluluk Verme.

Tablo 4. Düşmanın Kapasitesi ve Kötülüğü Teması

\begin{tabular}{|c|c|c|}
\hline Kategoriler & George W. Bush & François Hollande \\
\hline $\begin{array}{l}\text { Düşmanı } \\
\text { Tanımlama }\end{array}$ & $\sqrt{ }$ & $\sqrt{ }$ \\
\hline $\begin{array}{l}\text { Yerli } \\
\text { Terörizm } \\
\text { Vurgusu } \\
\end{array}$ & $\sqrt{ }$ & $\sqrt{ }$ \\
\hline $\begin{array}{l}\text { Düşmanın } \\
\text { Herkese } \\
\text { Zarar } \\
\text { Vermesi } \\
\end{array}$ & $\sqrt{ }$ & $\sqrt{ }$ \\
\hline $\begin{array}{l}\text { Medeniyet } \\
\text { Savaşı } \\
\text { Anlayışı }\end{array}$ & $\sqrt{ }$ & $\mathrm{X}$ \\
\hline $\begin{array}{l}\text { Müslüman } \\
\text { Ülkelere } \\
\text { Sorumluluk } \\
\text { Verme } \\
\end{array}$ & $\sqrt{ }$ & $\sqrt{ }$ \\
\hline
\end{tabular}

Düşmanın kapasitesi ve kötülüğü teması, iki liderin konuşma metinlerinde olan terörle savaş yaklaşımının diğer bir göstergesidir. Bush konuşmasında El Kaide'nin birçok Amerikan kurum ve askerlerine karşı saldırı gerçekleştiren bir örgüt olarak tanımlarken, bu terör örgüte mensup üyelerin ABD'de yaşayan ancak sonradan Afganistan'da kamplarda eğitim alarak ülkelerine dönen kişiler olduğunu belirtmektedir. "Topladı̆̆ımız kanıt, El Kaide olarak bilinen gevşek bağll terör örgütlerinin bir koleksiyonuna işaret ediyor. Tanzanya ve Kenya'daki Amerikan büyükelçiliklerini bombalamakla suçlanan ve USS Cole'u bombalamaktan sorumlu katillerden bazllarl" (Bush, 2001). Diğer taraftan Hollande, IŞİD'1n Müslüman ülkelerede zarar veren ve Fransız değerlerine karşı olan bir örgüt olarak tanımlamaktadır: "Saldırılar bir cihatçı ordu tarafindan, IŞID tarafindan yürütüldü, onlar bizimle savaşlyor çünkü Fransa bir özgürlük ülkesi çünkü insan haklarının doğum yeriyiz. -Bölgesel bir tabana, finansal kaynaklara ve askeri yeteneklere sahip bir kuruluş olan IŞID ile karşı karşıyayız"

İki lider yerli terörizmi özel olarak vurgulamaktadır. "60'tan fazla ülkede binlerce terörist var. Kendi uluslarından ve mahallelerinden toplanirlar ve terör taktikleri konusunda eğitildikleri Afganistan gibi yerlerde kamplara getirilirler. Kötülüğü ve yıkımı planlamak için evlerine geri gönderilir" (Bush, 2001). ABD'deki duruma benzer şekilde, yerli terörizm vurgusu Hollande'in konuşmasında da mevcuttur. Hollande: "Bunu söylemek acıtıyor, ama bunların cuma günü diğer Fransızlart öldürenlerin Fransızlar olduğunu biliyoruz. Burada topraklarımızda yaşayan, suç işleyerek başlayan, radikalleşen ve terörist olmaya devam eden bireyler. Bazen Suriye veya Irak'ta savaşmak için ayrllyorlar. Bazen, sponsorlart tarafindan belirlenen bir zamanda terörist eylemler yürütmek amaciyla, belirli durumlarda eğitim sağlayan veya birbirlerine yardım eden ağlar oluşturuyorlar" (Hollande, 2015).

Hollande, terörle savaşın medeniyet savaşından ziyade silahsız insanları hedef alan korkaklara yönelik bir savaş olduğunu belirtmiştir. "Kasıtlı olarak masumları hedef alarak onlart yok etmek isteyenler, silahsız bir kalabalığa ateş eden korkaklardır. Bir medeniyetler savaşı içinde olduğumuz söylenemez, çünkü bu suikastçıların temsil yetkisi yok. Sadece Fransa'yı değil, tüm dünyayı tehdit eden cihatçı terörizme karşs bir savaştayız" (Hollande, 2015). Ayrica, Hollande Müslüman veya İslam kelimesini kullanmamış, cihatçı kelimesini doğrudan kullanmıștır. Ayrıca, Müslüman ülkelerin adına yer vermiştir Ürdün, Türkiye ve Suriye gibi. Diğer taraftan, Bush'un konuşmasında, İslam ve Müslüman kelimeleri sı1kça yer almış ve Müslümanlara doğrudan seslenmiștir. Bush küresel bir savaş vurgusunu bu temada belirterek, bu savaşın bir medeniyet savaşı olduğunu belirtmiștir. "- $B u$ dünya savaşı. Bu medeniyetin kavgast. Bu, ilerlemeye ve çoğulculuğa, hoşgörü ve özgürlüğe inanan herkesin savaşıdır. Teröristler, Müslüman akademisyenler ve Müslüman din adamlarının büyük çoğunluğu tarafindan reddedilen, aşırılık yanlısı İslami aşırılıklar uyguluyorlar" (Bush, 2001). Ayrıca iki lider Müslüman ülkelere sorumluluk yüklemekte bu durumu Bush şöyle ifade etmektedir: "Ayrıca bu gece dünyadaki Müslümanlarla doğrudan konuşmak istiyorum. Inancınıza saygı duyuyoruz. Milyonlarca Amerikall tarafindan ve milyonlarca insan tarafindan Amerika'nın dost saydığı ülkelerde özgürce uygulanmaktadır. Öğretileri iyi ve huzurludur ve Allah adına kötülük yapanlar Allah'ın ismini küfretmektedir. Teröristler, gerçekte İslam'l gasp ederek gerçekte kendi inançlarına ihanet etmektedir" (Bush, 2001). Hollande ise "Fransa herkesle konuşuyor- Iran, Türkiye, Körfez Devletleri. Paris saldırlarl, Suriye'de siyasi bir çözüm bulmak için Viyana'da bu ülkelerle buluştuğumuz dönemde gerçekleşti. Şimdi hepimiz- komşu ülkeler, büyük güçler ve ayn zamanda Avrupa- sorumluluklarimızı yerine getirmeliyiz" (Hollande, 2015).

Bush terör örgütünün sadece ABD'ye değil Afganistan halkının kendisine olan zararını dile getirerek, terörle savaş temasını meşrulaştırırken, Afganistan'a askeri müdahalenin bölge halkının iyiliğine olduğunu dile getirmektedir. $\mathrm{Bu}$ durumu şöyle belirtmektedir: "El Kaide’nin liderliği Afganistan'da büyük etkiye sahip ve Taliban rejimini o ülkenin çoğunu kontrol etmede destekliyor. Afganistan'da El Kaide’nin dünya vizyonunu görüyoruz. Afganistan halkının birçoğu öldü ve birçoğu kaçtır” (Bush, 2001). Diğer taraftan, Hollande teröre destek veren ülkeler ayrımı yapmamaktadır. Saldırıların sadece Fransa'ya karşı yapılmadığını şöyle dile getirmektedir: “-Yılın başından bu yana, IŞID'ın terörist ordusu Paris, Danimarka, Tunus, Misır, Lübnan, Kuveyt, Suudi Arabistan, Türkiye ve 
Libya'ya saldırdı. Her gün insanlarl katlediyor ve eziyorlar. Bu yüzden IŞSiD’l yok etme ihtiyacl tüm uluslararası toplumu ilgilendirir" (Hollande, 2015).

Diğer bir tema uluslararası iş birliğine vurgudur ve 4 kategori belirlenmiştir: Teröre Destek Verenler ve Karşısında olan ülkeler Ayrımı, Saldırıların Sadece bir ülkeye karşı olmadığı İnancı, Diğer Devletlerden Destek Bekleme, Uluslararası Kurumlardan Destek Bekleme

Tablo 5. Uluslararası İş Birliği Teması

\begin{tabular}{lcc}
\hline Kategoriler & George W. Bush & François Hollande \\
\hline Teröre & & \\
Destek & $\sqrt{ }$ & $\mathrm{X}$ \\
Verenler ve & & \\
Karşısında & & \\
Olan Ülkeler & & \\
Ayrımı & & \\
\hline Saldırıların & & \\
Sadece bir & $\sqrt{ }$ \\
Ülkeye karşı & & \\
Olmadığı & & \\
Inancı & & \\
\hline Diğer & & \\
Devletlerden & $\sqrt{ }$ \\
Destek & & \\
Bekleme & & \\
\hline Uluslararası & & \\
Kurumlardan & $\sqrt{ }$ \\
Destek & & \\
Bekleme & & \\
\hline
\end{tabular}

ABD ve Fransa'nın terörle mücadelede uluslararası işbilirliği teması dikkat çekmektedir. Bush teröre destek veren ülkelerin teröristlerle aynı muameleyi göreceğini ve ülkelerin açık bir tercih yapmasının zorunluğu olduğunu dile getirmektedir. "-Ve terörizme yardım ya da güvenli sığınak sağlayan ulusları takip edeceğiz. Artık her bölgedeki her ulusun bir kararl var: Ya bizimle ya da teröristle birliktesin.-Bugünden itibaren, terörizmi barındirmaya veya desteklemeye devam eden uluslar $A B D$ tarafindan düşmanca bir rejim olarak kabul edilecektir" (Bush, 2001).

Üstelik bu mücadelenin sadece ABD tarafindan yapılmadı̆̆ı, diğer devletlerinde kendi özgürlükleri için medeniyet savaşına dahil olduğunu dile getirmektedir. “Ancak bu sadece Amerika'nın kavgası değil. Ve tehlikede olan sadece Amerika'nın özgürlüğ̈̈ değildir. Bu dünya savaşı. Bu medeniyetin kavgası" (Bush, 2001). Bu coğulculuğa, hoşgörü ve özgürlüğe inanan herkesin savaş1 olarak sunulmaktadır. ABD, dünyanın tüm devletlerinden destek aldığınıda vurgulamaktadır. "Her ulustan bize katılmasını istiyoruz. Dünyadaki polis güçlerinin, istihbarat servisinin ve bankacıllk sistemlerinin yardımını istiyoruz ve ihtiyacımız olacak. ABD birçok ulusun ve birçok uluslararası örgütün Latin Amerika'dan Asya'ya, Afrika'dan Avrupa'ya ve İslam dünyasına şimdiden sempati ve destek aldı ̆̆ için minnettardır" (Bush, 2001). NATO’yu da göreve çağırmaktadır. Hollande bölgesel desteğe vurgu yapmakta, yani AB'nin ortak bir duruş sergilemesini istemektedir.
"Savunma bakanından yarın Avrupalı meslektaşlarımızla AB Antlaşması'nın 42 (7) maddesi, dayanışma hükmü uyarınca, bir Devlete saldırldı̆̆ında tüm Üye Devletlerin yardım ve destek sağlamakla yükümlü olduğu, çünkü düşman sadece Fransa'nın düşmanı değil aynı zamanda Avrupa'nın düşmanıdır" (Hollande, 2015). Sonra, Hollande, düşmanın Suriye ve çevresindeki ülkelere zarar vermesinden bahsetmekte ve bu yüzden bölgesel ve uluslararası toplumun sorumluluğununda altını çizmektedir. “Önümüzdeki birkaç gün içinde, kuvvetlerimizi birleştirmek ve bu noktada çok uzun süre ertelenmiş bir sonuç elde etmek için Başkan Obama ve Başkan Putin ile görüşeceğim" (Hollande, 2015). Ülkelerin diş politikası terör saldırıları sonrası daha yoğun bir hal almakta ve uluslararası bir dayanışmanın gerekliliğinin altı çizilmektedir.

İki metin incelendikten sonra belirlenen son tema askeri ve idari düzenlemedir ve bu tema için 3 kategori belirlenmiştir: İç Güvenlik Unsurlarını Güçlendirme, İdari Düzenlemeler, İstihbarat Güçlendirme.

Tablo 6. Askeri ve İdari Düzenleme Teması

\begin{tabular}{lcc}
\hline Kategoriler & George W. Bush & François Hollande \\
\hline Ulusal & $\sqrt{ }$ & $\sqrt{ }$ \\
Güvenlik & & \\
Unsurlarını & & \\
Güçlendirme & & $\sqrt{ }$ \\
\hline İdari & & \\
$\begin{array}{l}\text { Düzenleme } \\
\text { Yapma }\end{array}$ & $\sqrt{ }$ & $\sqrt{ }$ \\
\hline İstihbaratı & & \\
Güçlendirme & $\sqrt{ }$ & \\
\hline
\end{tabular}

Terör saldırılarının ulusal politikaları etkilendiğinin altını çizen temalardan birisi idari ve yasal düzenlemeler temasıdır. Bush istihbaratı ve terörle mücadelede koordinasyonu güçlendirmeye yönelik atılacak adımları belirtmektedir. Terör saldırıları sonrası, ulusal düzeyde yeni düzenlemeler dikkat çekmektedir. İki liderin konuşmasında, devletin tüm kurum ve birimlerine sorumluluk düştüğünün altı çizilmektedir. "-Bugün, düzinelerce federal birim ve ajansin yanı sira eyalet ve yerel yönetimlerin, ülke güvenliğini etkileyen sorumluluklarl vardır. -Bu çabalar en üst düzeyde koordine edilmelidir. Bu gece, doğrudan bana rapor bildirecek, Kabin düzeyinde bir pozisyon, Ulusal Güvenlik birimi oluşturulduğunu duyuruyorum” (Bush, 2001).

Bush idari düzenlemelerin yapılacağını ve bazılarının çok önemli kurumlar olacağını belirtmektedir "Hava güvenliğini iyileştirmek, iç hat uçuşlarındaki Hava Mareşali sayısını önemli ölçüde artırmak ve uçak kaçırmayı önlemek için yeni önlemler almak için bir araya geleceğiz", (Bush, 2001). Ayrıca istihbarat güçlerinin geliştirileceği belirtilmektedir. "Teröristlerin harekete geçmeden önce planlarını bilmek ve saldırıdan önce bulmak için istihbarat kapasitemizi güçlendirmek için bir araya geleceğiz" (Bush, 2001). 
Hollande'in konuşması ise ağırlıklı olarak yasal, askeri ve idari düzenlemelere yöneliktir. "Önümüzdeki iki yll içinde, 5 yıl boyunca güvenlikle ilgili çalışanları 10 bin kişiye çıkarması amacıla, 5 bin ilave polis ve jandarma alınarak iş yaratılacak.-Benzer şekilde, Adalet Bakanliğ hapishane hizmetine ve yargl hizmetine 2.500 ilave iş daha ekleyecektir. Ve gerekirse sınır kontrolünü sağlamak için 1000 çallşana daha ihtiyaç duyan gümrük servisini de unutmamalıyım" (Hollande, 2015). Olağanüstü halin ilanı, anayasal değişimler, asker, polis ve yargıç sayısının artırılması, vatandaşlıktan çıkarma gibi değişim taleplerini dile getirmektedir. Bu doğrultuda Hollande, idari ve yasal düzenlemeleri şöyle belirtmektedir: "Olağanüstü hali üç ay boyunca uzatan, içeriğini tehdit ve teknolojideki değişikliklere uyarlayan bir tasarının çarşamba günü Parlamento'ya getirilmesine karar verdim. -Vatandaşlıktan çıkarma, birisini vatansız hale getirmemeli, ancak Fransız vatandaşlı̆̆ını, bir Fransız insanı olarak doğmuş olsa bile başka bir milliyete sahipse, bir ülkenin temel çıkarlarına karşı terörist bir suçtan veya başka bir fiilden suçlu bulunan bir kişiyi vatandaşlıktan çıkarabilmeliyiz" (Hollande, 2001). Hollande, ayrıca, Bush gibi istihbaratın güçlendirileceğini vurgulamaktadır. Bush, "teröristlerin harekete geçmeden önce planlarını bilmek ve saldırıdan önce bulmak için istihbarat kapasitemizi güçlendirmek için bir araya geleceğiz” (Bush, 2001). Diğer taraftan, Hollande, "tehdit devam edeceğinden ve yurt dişında ve evde uzun süre IŞİD ile mücadeleye katılacağımız için, adalet sistemi ve güvenlik güçleri için mevcut kaynaklart önemli ölçüde güçlendirmeye karar verdim. -Bu hükümler, 2012'den bu yana kabul edilen tüm önlemleri, yani iki terörle mücadele yasasını, bir istihbarat yasasını, kaynakların önemli ölçüde güçlendirilmesini tamamlayacaktır" (Hollande, 2015). Özetle, iki liderin konuşmalarında terörle savaş yaklaşımının benzer yanlarıyla birlikte hem uygulamada hem de söylemde farklılıklar içerdiği görülmektedir.

\section{Sonuç}

11 Eylül 2001 ve 13 Kasım 2015 terör saldırıları sonrası geliştirilen terörle savaş yaklaşımı birbirlerine benzer görülse de farklı unsularıda içermektedir. Bu iki ülke teröre karşı benzer bir risk algısı hissederek benzer çözümler üretme yolunu tercih etmiştir. Terörle mücadelede uygulanan yöntemler giderek birbirlerine yaklaşmış ve terörle savaş yaklaşımı benimsenmiştir. İki lider de kendi ülkelerinde maruz kaldıkları savaş eylemlerine bir karşılık olarak ülkelerinin bir savaşta olduğunu belirtmiştir. Bu durumda, iki liderin konuşmalarındaki saldırganların neden kendi ülkelerini hedef aldıkları ve saldırılarla ilişkilendirme tarzları birbirlerine benzemektedir.

Terörle savaş yaklaşımı inşa edilirken iki lider de kurum ve vatandaşlarına duydukları inancı belirtmişlerdir. Devletin kurum ve vatandaşlarıyla bu savaşın içinde olacağı ve terörle savaşta gerekli kaynakların sağlanacağı belirtilmektedir. Bu noktada, Fransa, Fransız vatandaşlarını yüceltme yolunu tercih ederken, ABD fedakâr Amerikalılar ve özellikle askeri ve idari kurumların fedakarlıklarından bahsetmiştir.
İki liderin konuşmasında, terörle savaş yaklaşımı tehlikeli bir düşmanın varlığından beslenmiştir. Tehlikeli bir düşmana karşı kendini savunma hakkı terörle savaşın meşrulaştırılmasında önemli bir rol oynamıştır. Bush konuşmasında, düşmanın uzun zamandır ABD'ye zarar verdiğini, ancak zararın ilk defa bu boyutlara çıkmasının verilecek karşılığı da büyüttüğünün altını çizmektedir. Bush, düşmanla işbirliği yapanların da düşmanla aynı kategoriye sokulacağını belirtmiştir. Bush'un düşmanı tasvir edişi dikkat çekicidir. Düşman kendi insanlarına zulüm eden bir oluşum olarak değerlendirilmiştir. Böylelikle, Bush'un Afganistan'a müdahalesi yerel halka yapılan bir iyilik olarak değerlendirilmiștir. Ayrıca, Taliban El Kaide'ye sağladığı imkân ve desteklerden dolayı hedefe alınmaktadır. Diğer taraftan, Hollande'ın konuşmasında düşmanın kapasitesi değerlendirilirken, Fransa'nın korunması gereken değerleri ön plana çıkarılmış ve bu değerlerin korunması terörü savaşla engellemeyle gerçekleştirilebilecektir.

Hem Bush'un hem de Hollande'in konuşmalarında terörle savaşın İslam'la savaş olmadığı vurgusu görülmektedir. Ancak, bu noktada iki lider arasında keskin bir ayrım bulunmaktadır. Hollande, terörle savaşın medeniyet savaşından ziyade silahsız insanları hedef alan korkaklara yönelik bir savaş olduğunu belirtmiştir. Ayrıca, Hollande Müslüman veya İslam kelimesini kullanmamış, cihatçı kelimesini doğrudan kullanmıștır. Ayrıca, Ürdün, Türkiye ve Suriye gibi ülkelerin isimleri verilerek bazı Müslüman ülkelerin isimleri belirtilmiştir. Diğer taraftan, Bush'un konuşmasında, İslam ve Müslüman kelimeleri sıkça yer almış ve Müslümanlara doğrudan seslenmiştir. Bush'un konuşması doğrudan müslümanları ilgilendiren birçok kısım barındırmaktadır. Masumları öldüren Müslümanların hedefte olduğu, ancak diğer müslümanların da niyet ve çabalarını açıkça göstermelerinin beklendiği bir resim çizmiştir. Sonuçta, Bush'un konuşmasında terörle savaşın İslam'a karşı bir savaş olmadığı siyasi ve ideolojik unsurlara yönelik olduğun belirtmektedir. $\mathrm{Bu}$ minvalde, terörle savaş yaklaşımı da özgürlük ve demokrasi yolunda bir gereklilik olarak sunulmaktadır.

ABD ve Fransa'nın terörle mücadelede uyguladıkları terörle savaş yaklaşımında ortak bir eğilim ulusal ve dış politikayı yönlendirici etkisinin meydana gelmesidir. $\mathrm{Bu}$ durum kendisini uluslararası işbilirliği temasında göstermektedir. Bush teröre destek veren ülkelerin teröristlerle aynı muameleyi göreceğini ve ülkelerin açık bir tercih yapmasının zorunluğu olduğunu dile getirmektedir. Üstelik bu mücadelenin sadece ABD tarafindan yapılmadığı, diğer devletlerin de kendi özgürlükleri için medeniyet savaşına dahil olduğunu dile getirmektedir. $\mathrm{Bu}$ çoğulculuğa, hoşgörü ve özgürlüğe inanan herkesin savaşı olarak sunulmaktadır. ABD, dünyanın tüm devletlerinden destek aldığını da vurgulamaktadır. NATO'yu göreve çağırmaktadır. Diğer taraftan, Hollande bölgesel desteğe vurgu yapmakta, yani AB'nin ortak bir duruş sergilemesini istemektedir. AB'nin rolü, Fransa'nın ulusal ve bölgesel güvenliğini $\mathrm{AB}$ çerçevesinde ele aldığını göstermektedir. Hollande yine düşmanın Suriye ve çevresindeki ülkelere zarar vermesinden bahsetmekte ve bu yüzden bölgesel ve uluslararası toplumun sorumluluğununda altını çizmektedir. Ülkelerin dış politikası terör saldırıları sonrası daha yoğun 
bir hal almakta ve uluslararası bir dayanışmanın gerekliliğin altı çizilmektedir.

Ulusal polikalarında etkilendiğinin altını çizen son tema idari ve yasal düzenlemeler temasıdır. Bush istihbaratı ve terörle mücadelede koordinasyonu güçlendirmeye yönelik atılacak adımları belirtmektedir. Terör saldırıları sonrası, ulusal düzeyde yeni düzenlemeler dikkat çekmektedir. İki liderin konuşmasında, devletin tüm kurum ve birimlerine sorumluluk düştüğünün altı çizilmektedir. ABD'de, örneğin, Ulusal Güvenlik ve yeni uçuş düzenlemeleri bunun vücut bulmuş halidir. Hollande'in konuşması ise ağırlıklı olarak yasal, askeri ve idari düzenlemelere yöneliktir. Olağanüstü halin ilanı, anayasal değişimler, asker, polis ve yargıç sayısının artırılması, vatandaşlıktan çıkarma gibi değişim taleplerini dile getirmektedir.

Terörle savaş yaklaşımının diğer bir ortak eğilimi, terör saldırıları sonrasında askeri kurumların güçlendirilmesi ve askeri ve polis sayılarının artırılması, yani bir askerileşmeyi de beraberinde getirmesidir. Bush ve Hollande'in terörle savaş yaklaşımı karşılaştırıldığında, öncü konumda olan ABD'nin terörle savaş yaklaşımının, Fransa'nın yaklaşımıyla kıyaslandığında daha fazla askeri odaklı ve medeniyetler savaşı üzerine inşa edilirken, Fransız terörle savaş yaklaşımının askeri yönleriyle ve medeniyet savaşından boyut olarak daha sınırlı olduğu görülmektedir. İki ülke içinde, terörle savaş yaklaşımı hem ulusal hem de dış politika açısından yeni dinamiklerin oluşturulduğu bir dönemi başlatmıştır.

Çalışmada elde edilen bulgular bizi iki liderin terörle savaş yaklaşımı açısından birbirlerine yakın bir dil geliştirirken, uygulamada farklı dinamiklerin göz önüne alındığı bir yolu göstermesidir. Bir yandan yasal ve kurumsal düzenlemelerin gerekliliğinin altını çizen liderler, diğer yandan doğrudan askeri müdahalelerden, gizli operasyonlara kadar çeşitli araçları terörle mücadelede kullanılacak araçlar arasında saymakta tereddüt etmemiştir. Hollande saldırıların ardından konuşmasında uzun tartışmalı süreçleri sonucunda yasal düzenlemeleri kullanırken, Bush doğrudan Başkanlığın yetkilerinden yararlanmıştır. Fransız yaklaşımı bu arada soğuma süresine girmiş ve terörle mücadele yaklaşımına yaklaşırken, Bush'un Afganistan müdahalesi Irak'ın işgaline kadar küresel bir boyuta ulaşmıştır. Fransa'nın AB'yle olan ilişkisi küçük bir sınavdan geçerek, uluslararası iş birliğine dayalı bir yaklaşım sergilerken, Bush uluslararası iş birliğinde 'ya bizimlesiniz ya teröristlerle' söylemiyle zorlayıcı bir yaklaşım benimsemiştir. Sonuçta, terörle savaş yöntemi yurtdışı askeri operasyonlardan, gizli operasyonlara bir yandan askeri yönü ön planda olan, göçmenlik ve bazı sivil hakların güvenlik unsuru haline geldiği gerek yasal gerek idari düzenlemelerin hem iç hem de dış politikayı şekillendirici bir dönüşüme neden olduğu görülmektedir.

\section{Kaynakça}

9/11 Komisyon Raporu. (tarih yok). Tthe 9/11 Commission Report Final Report of the National Commission on Terrorist Attacks Upon the United States. National Commission on Terrorist Attacks.
Abdo, M. (2015, Erișim Tarihi: 29 Haziran 2020). A Critical Discourse Analysis of George W. Bush's Speech An Appeal to Muslims: Address to the United Nations.

https://www.researchgate.net/publication/327270369 _A_Critical_Discourse_Analysis_of_George_W_Bu sh\%27s_Speech_An_Appeal_to_Muslims_Address_ to_the_United_Nations adresinden alındı

d'Abadie, D. S., (2003), from 11/9 to 9/11:Contunity or Change in International Politics, Outone-Inverno, pp.123-134

Ballesteros, A., 2018, Counter-Terrorism Efforts in Spain, Counter Terrorist Trends and Analyses, Vol. 10, No. 11, pp.9-13

BBC, (2016), https://www.bbc.com/news/world-europe35924701 Son Erişim Tarihi: 06.10.2020

Beauchamps, M. (2020, Haziran 21). Denaturalisation, 'Terrorism' and National Identity in France. https://d1wqtxts1xzle7.cloudfront.net/45345526/exp losivepolitics.com-

Denaturalisation_Terrorism_and_National_Identity_ in_France.pdf?1462367173=\&response-contentdisposition=inline $\% 3 \mathrm{~B}+$ filename $\% 3 \mathrm{DD}$ enaturalisati on_Terrorism_and_National.pdf\&Expires $=1592764$ 25 adresinden alınd 1

Berschinski, R. G. (2007). Afrucom's Dilemma: The "Global War on Terrorlsm," "Capacity Bullding," Humanitarianism, and The Future ff U.S. Security Policy in Africa. https://www.peacepalacelibrary.nl/ebooks/files/3712 1954X.pdf, : Title 17, United States Code, Section 101.

Beshara, R. K. (2018). A critical discourse analysis of George W. Bush's 'War on Terror' speech: the rhetoric of (counter)terrorism and the logic of Islamophobia. Journal of Language and Discrimination, Vol.2, No.1, 85-122.

Blakeley, R. (2017). British torture in the 'war on terror'. European Journal of International Relations, Vol. 23, No. 2, DOI: 10.1177/1354066116653455, 243266.

Blanchard, M. C. and Humud, E. C., 2018, The Islamic Satate and U.S Policy, Congressiona Research Service, rapor

Boutin, B. (2016). The Use and Abuse of Administrative Measures against FTFs in France. ICCT The Hague.

Bush, G. W. (2001, Eylül 20). Text: President Bush Addresses the Nation. https://www.washingtonpost.com/wpsrv/nation/specials/attacked/transcripts/bushaddress_ 092001.html adresinden alınd

Brisard, J-C. 2015, The Paris Attacks and the Evolving Islamic State Threat to France, CTCSENTINEL, Vol.8, No.11

Bymann, D.L., 2011, The History of Al-Qaeda https://www.brookings.edu/opinions/the-history-ofal-qaeda/ Erşim Tarihi: 12.09.2020 
Calamur, K.,2017, How Did Spain Avoid Terrorism Before Barcelona?, "https://www.theatlantic.com/international/archive/2 017/08/barcelona-attack-spanishcounterterrorism/537336/" Son Erişim tarihi: 05.10.2020

Chalkiadaki, V. (2015). The French "War on Terror" in the post-Charlie Hebdo Era. EUCRIM The European Criminal Law Association's Forum, 26-32.

CIA, 2002, https://www.cia.gov/newsinformation/speeches-

testimony/2002/DCI_18_June_testimony_new.pdf Son Erişim Tarihi: $0 \overline{6} \cdot 10.2020$

Colijn, K., Singleton, M., Ginkel, B. v., Chauzal, G., \& Zavagli, S. (2015). Paris: 11/13/15 Analysis and Policy Options. https://www.clingendael.org/sites/default/files/pdfs/ Policy_Brief_Clingendael_ICCT-

Paris111315Analysis_and_Policy_Options_Novemb er\%202015_final.pdf Erişim Tarihi: 25 Haziran 2020: Clingendael ve Centre for Counter-Terrorism - The Hague (ICCT).

Cottey, A. (2003)," Afghanistan and the new dynamics of intervention: counter-terrorism and nation building" SIPRI Yearbook 2003: Armaments, Disarmament and International Security

Cox, M. (2002). Paradigm Shifts And 9/11: International Relations After The Twin Towers. Security Dialogue,33(2), 247-251. Retrieved October 6, 2020, from http://www.jstor.org/stable/26298072

Daniel,K., 2015,The Black Friday Paris Attack Waht Do We Know? What Should We Do?, Special Report, International Institute for Counter-Terrorism, https://www.ict.org.il/UserFiles/ICT-The-BlackFriday-Paris-Attacks-Nov15.pdf, Erişim tarihi: 12.09.2020

Dück, E., \& Lucke, R. (2019). Same Old (Macro-) Securitization? A Comparison of Political Reactions to Major Terrorist Attacks in the United States and France. Croatian International Relations Review, Vol. 25, No. 84, DOI 10.2478/ cirr-2019-0001, 1-30.

Daalder, I. H., \& Lindsay, J. M. (2001, Aralık 1). Nasty, Brutish and Long: America's War on Terrorism. Erişim tarihi 25.06.2020: https://www.brookings.edu/articles/nasty-brutishand-long-americas-war-on-terrorism/ adresinden alınd 1

Encyclopaedia Britannica, Inc. (2020, Haziran 25). War on terrorism. Encyclopaedia Britannica: https://www.britannica.com/print/article/1247283 adresinden alınd 1

Eriksson, J. (2013). The 'Clash of Civilizations' and Its Unexpected Liberalism. J. P. (ed.) içinde, The Clash of Civilization: Twenty Years On (s. 20-30). Bristol: e-International Relations.

France25, 2015, France Strikes Islamic State group in Syria, Iraq from Aircraft Carrier, https://www.france24.com/en/20151123-france- charles-de-gaulle-carrier-strikes-targets-iraq,

Son Erişim Tarihi: 06.10.2020

Gershkoff, A., \& Kushner, S. (2005). Shaping Public Opinion: The 9/11-Iraq Connection in the Bush Administration's Rhetoric. Perspectives on Politics, Vol. 3, No.3, 525-537.

Günbayı,I., Nitel Araştırmada Veri Analizi: Tema Analizi, Betimsel Analiz, İçerik Analizi ve Analitik Genelleme, Nirvana Sosyal Bilimler Sitesi, http://www.nirvanasosyal.com/h-392-nitelarastirmada-veri-analizi-tema-analizi-betimselanaliz-icerik-analizi-ve-analitik-genelleme.html, Son Erişim tarihi: 06.10.2020

Gordon, P. H. (2007). Can the War on Terror Be Won? How to Fight the Right War. Foreign Affairs, Vol.86, No.6, 53-66.

Gomes, T. A., Mikhael, M.M, 2018, Terror or Terrorism? Al-Qaeda and Islamic State in Comparative Perspective, A Journal of the Brazilian Political Science Association, Vol.12, No.1

Gurski, P. (2018). An End to the War on Terrorism. ICCT, The Hague.

Hecker, M., \& Tenenbaum, E. (2017). France vs. Jihadism: The Republic in a New Age of Terror. Notes de I'FRI, Security Studies Center.

Hollande, F. (2015, Kasim 16). Speech by the President of the Republic before a joint session of Parliament (Versailles, November 16, 2015). https://www.diplomatie.gouv.fr/en/french-foreignpolicy/security-disarmament-and-nonproliferation/news/news-about-defence-andsecurity/article/speech-by-the-president-of-therepublic-before-a-joint-session-of-parliament adresinden alınd

Jackson, R. (2005). Security, Democracy, and the Rhetoric of Counter-Terrorism. Democracy and Security, 1, DOI: 10.1080/17419160500322517, 147-171.

Jasko, K., Kruglanski, A.W., Bin Hassan, A.S.R.,

Gunaratna, R., ISIS: Its History,Ideology,and Psychology, içideHandbook of Contemporary Islam and Muslim Lives, Springer,Cham

Jones, S.G. Dobbins, J., Bymann, D. Chivvis, C.S., Connable, B., Martini, J., Robinson, E. Chandler, N. Rolling Back the Islamic State, 2017, Rand Cooperation,

https://www.rand.org/pubs/research_reports/RR1912 .html. Erişim tarihi: 04.10.2020

Maulny, J.-P. (2017). Democracy and Terrorism Experience in Coping with Terror Attacks in France. A. M. (Ed.) içinde, Democracy and Terrorism Experiences in Coping with Terror Attacks Case Studies from Belgium, France, Israel and Norway (s. 15-31). Friedrich Ebert Stiftung, International Policy Analysis,.

Mignot-Mahdavi, R. (2020). Le Silence des Agneaux: France's War Against 'Jihadist Groups' and Associated Legal Rationale. ICCT Research paper, DOI: 10.19165/2020.1.02 ISSN: 2468-0486. 
Murphy, R. (2016). France's war on terror: a domestic or foreign threat? Politics Review, Vol. 25, No. 4.

Montalvo, J. G. 2011. "Voting after the Bombings: A Natural Experiment on the Effect of Terrorist Attacks on Democratic Elections", Review of Economics and Statistics, 93 (4),1146-1154.

Naidenov, B. (2020, Erişim Tarihi: 21 Haziran 2020). An Evaluative Study of Operation Sentinelle: The French Response to its Domestic Terrorism Threat. https://www.academia.edu/33024759/AN_EVALU ATIVE_STUDY_OF_OPERATION_SENTINELL E adresinden alınd1

Post 9/11 Major Military Operations. (2020, Haziran 28). https://schoolresources.militaryfamilies.psu.edu/wpcontent/uploads/2017/08/post_9-

11_major_military_operations.pdf adresinden alındı

Reese, S. (2007). The Framing Project: A Bridging Model for Media Research Revisited. Journal of Communication , DOI: 10.1111/j.14602466.2006.00334.x, 148-154.

Reese, S. D., \& Lewis, S. C. (2009). Framing the War on Terror The internalization of Policy in the US Press. Journalism, Vol. 10, No. 6, DOI: 10.1177/1464884909344480, 777-797.

Reinares F.(2009) After the Madrid Bombings: Internal Security Reforms and Prevention of Global Terrorism in Spain, Studies in Conflict \& Terrorism, 32:5, 367-

388, DOI: $10.1080 / 10576100902836767$

Revkin, M., The Legal Foundations of the Islamic State, The Brookings Project on U.S. Relations with the Islamic World, Analyses paper, No.23. 2016

Rosenau, W. ve Powell,(2017) A. Al QaedaCore: A Case Study, CNA Analysis and Solutions

Oosterveld, W.T ve Bloem, W. 2016-2017, The Rise and Fall of ISIS: From Evitability to Inevitability rapor

Samaan, J.-L., \& Jacobs, A. (2018). Countering Jihadist Terrorism: A Comparative Analysis of French and German Experiences. Terrorism and Political Violence, Vol.32, No.2, 401-415.

Scheffer, A. d., Michelot, M., \& Quencez, M. (2016). After the Terror Attacks of 2015 A French Activist
Foreign Policy Here to Stay? . Paris: The German Marshall Fund of the United States, GMF.

Schofield, H. (2015, Kasim 16). Paris attacks: 'France will destroy IS' - Hollande. https://www.bbc.com/news/world-europe-34836439 adresinden alındı

Sert, G., Kurtoğlu, M., Akınc1, A., \& Seferoğlu, S. S. (2012). Öğretmenlerin Teknoloji Kullanma Durumlarını İnceleyen Araştırmalara Bir Bakış: Bir İçerik Analizi Çalışması. Akademik Bilişim'12 - XIV. Akademik Bilişim Konferansı Bildirileri (s. 351357). Uşak: Uşak Üniversitesi.

Templeton, E. (2019). The Role of Socialisation in the Deradicalisation Process: A Promising Long-Term Strategy? Charles University Faculty of Social Sciences:

https://www.academia.edu/42203827/The_Role_of_ Socialisation_in_the_Deradicalisation_Process_A_P romising_Long-Term_Strategy adresinden alındı

U.S. Department of State Archive. (2009). The Global War on Terrorism: The First 100 Days. Washington, London, Islamabad: U.S. Department of State.

Wayne, M. I. (2009). Inside China's War on Terrorism. Journal of Contemporary China, Vol. 18, No.59, 249-261.

Weill, S. (2018). Terror in Courts, French counterterrorism: Administrative and Penal Avenues. Paris: Report for the official visit of the UN Special Rapporteur on Counter-Terrorism and Human Rights, The Capstone Course on Counter-Terrorism and International Crimes, PSIA, Sciences-Po.

White House. (2003). National Strategy for Combating Terrorism. https://www.cia.gov/newsinformation/cia-the-war-on-

terrorism/Counter_Terrorism_Strategy.pdf, Erişim Tarihi: 27 06.2020.

Wright, R., Berger, J.M., Braniff, W. Bunzel, C., Bymann, D., Cafarella, J., Gambhir, H., Garternstein-Ross, D.,Hassan, H., Lister, C., McCants, W., Nada, G., Olidort, J., Thurston, A., Watts, C., Wehrey, F., Whiteside, C., Wood, G., Zelin, A.Y., Zimmerman, K., The Jihadi Threat ISIS, al-Qaeda, and Beyond, United States Instititute of Peace, 2016-2017

Yıldırım, A., \& Şimsek, H. (2005). Sosyal Bilimlerde Nitel Araştırma Yöntemleri. Ankara: Seçkin Yayıncılık. 